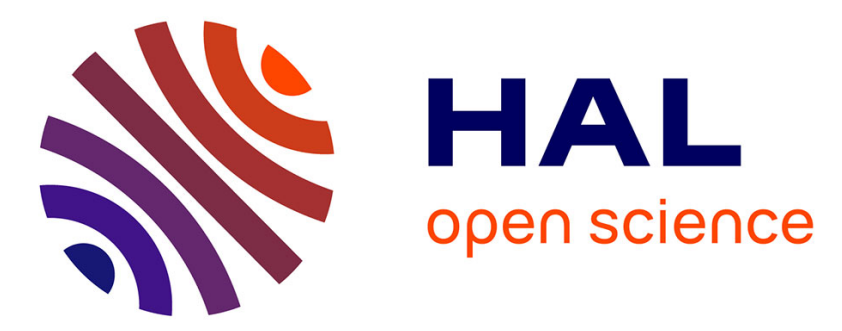

\title{
Rise and emplacement of magma during horizontal shortening of the brittle crust: Insights from experimental modeling
}

Olivier Galland, P.R. Cobbold, Jean de Bremond d'Ars, Erwan Hallot

\section{- To cite this version:}

Olivier Galland, P.R. Cobbold, Jean de Bremond d'Ars, Erwan Hallot. Rise and emplacement of magma during horizontal shortening of the brittle crust: Insights from experimental modeling. Journal of Geophysical Research: Solid Earth, 2007, 112 (B6), pp.B06402. 10.1029/2006JB004604 . insu00155139

HAL Id: insu-00155139

https://hal-insu.archives-ouvertes.fr/insu-00155139

Submitted on 30 Mar 2016

HAL is a multi-disciplinary open access archive for the deposit and dissemination of scientific research documents, whether they are published or not. The documents may come from teaching and research institutions in France or abroad, or from public or private research centers.
L'archive ouverte pluridisciplinaire HAL, est destinée au dépôt et à la diffusion de documents scientifiques de niveau recherche, publiés ou non, émanant des établissements d'enseignement et de recherche français ou étrangers, des laboratoires publics ou privés. 


\title{
Rise and emplacement of magma during horizontal shortening of the brittle crust: Insights from experimental modeling
}

\author{
Olivier Galland, ${ }^{1,2}$ Peter R. Cobbold, ${ }^{1}$ Jean de Bremond d'Ars, ${ }^{1}$ and Erwan Hallot ${ }^{1}$
}

Received 29 June 2006; revised 30 October 2006; accepted 16 January 2007; published 7 June 2007.

[1] Magmatic activity tends to concentrate at plate margins. At divergent margins, extensional tectonics provide steep conduits for magma to reach the surface. At rapidly convergent margins, such as the Andes, one might imagine that horizontal compression prevents the rise of magma. Nevertheless, volcanoes are also common. In order to study the mechanisms by which magma rises in a compressional context, we resorted to laboratory experiments, in which a brittle crust was shortened, while magma was intruding. Our model materials were (1) cohesive fine-grained silica powder, representing brittle crust, and (2) molten low-viscosity vegetable oil, representing magma. In general, horizontal shortening and injection were coeval but independent processes. Thrust faults accommodated the shortening, while overpressured oil formed hydraulic fractures. In those experiments where there was no shortening, injection resulted in a saucer-shaped intrusive body. In the other experiments, where there was shortening, oil formed a basal sill, before rising along thrust faults. Once in place, the sill lubricated the base of the model, so that arcuate thrusts formed at the leading edge of a plateau. Uplift of the plateau promoted further intrusion of oil at depth. In general, the pattern of deformation and intrusion depended on the kinematic ratio $R$ between rates of shortening and injection. The lengths of the basal sill and plateau increased with decreasing $R$. On the basis of these results, we have reexamined two natural examples of magmatic complexes, which were emplaced in compressional tectonic settings, Tromen volcano in Argentina and the Boulder Batholith of Montana.

Citation: Galland, O., P. R. Cobbold, J. de Bremond d'Ars, and E. Hallot (2007), Rise and emplacement of magma during horizontal shortening of the brittle crust: Insights from experimental modeling, J. Geophys. Res., 112, B06402, doi:10.1029/2006JB004604.

\section{Introduction}

[2] Magmatic activity tends to concentrate at plate margins. Volcanism is especially common in areas of extensional tectonics, and notably so at divergent margins. In such settings, magma intrudes the brittle crust by hydraulic fracturing. It forms subvertical dikes, which are perpendicular to the least principal stress [Hubbert and Willis, 1957; Sibson, 2003]. These may or may not reach the surface [Ida, 1999; Gudmundsson, 2002]. Good examples of such dikes are to be found in the Icelandic rift system [Gudmundsson, 1984; Helgason and Zentilli, 1985].

[3] In compressional settings, it is widely assumed that magma cannot rise so easily [e.g., Watanabe et al., 1999]. The arguments for this are mainly theoretical. If the least principal stress is vertical, hydraulic fractures will be horizontal [Hubbert and Willis, 1957; Sibson, 2003] and therefore will not lead directly to the surface. Moreover, the magmatic pressure required to propagate a tabular body will

\footnotetext{
${ }^{1}$ Géosciences-Rennes (UMR6118 du CNRS), Universite de Rennes, Rennes Cedex, France.

${ }^{2}$ Now at PGP (Physics of Geological Processes), Universitet i Oslo, Sem Selands vei 24, NO-0316 Oslo, Norway.

Copyright 2007 by the American Geophysical Union. 0148-0227/07/2006JB004604\$09.00
}

be higher in compression than it is in extension [Sibson, 2003]. On this basis, many authors have claimed that volcanic activity should be rare if not absent in compressional settings [Glazner, 1991; Hamilton, 1995].

[4] However, field evidence seems to contradict this premise. In the early twentieth century, Eugène Wegmann argued that granitic magma rises along thrust faults [Schaer, 1995]. More recently, several examples have been described of orogenic plutons, for which emplacement has been synchronous with horizontal shortening (see review in Hutton [1997]; also Kalakay et al. [2001]; Lageson et al. [2001]; Musumeci et al. [2005]).

[5] At the surface, active volcanoes are common at rapidly convergent margins, which are under horizontal compression. A good example is the Andean margin of South America [Schäfer and Dannapfel, 1994], which is actively shortening, according to Global Positioning System (GPS) measurements (Figure 1a [Norabuena et al., 1998; Kendrick et al., 2001]). Recently, it has become apparent that some Andean volcanoes lie along major thrust faults. Good examples are Guagua Pinchincha in Ecuador [Legrand et al., 2002], Taapaca in Chile [Clavero et al., 2004], Socompa in Chile [van Wyk de Vries et al., 2001], El Reventador in Ecuador [Tibaldi, 2005], and Tromen in Argentina (Figure 1b [Kozlowski et al., 1996; Marques and Cobbold, 2002; Galland et al., 2007]). On El Reventador 


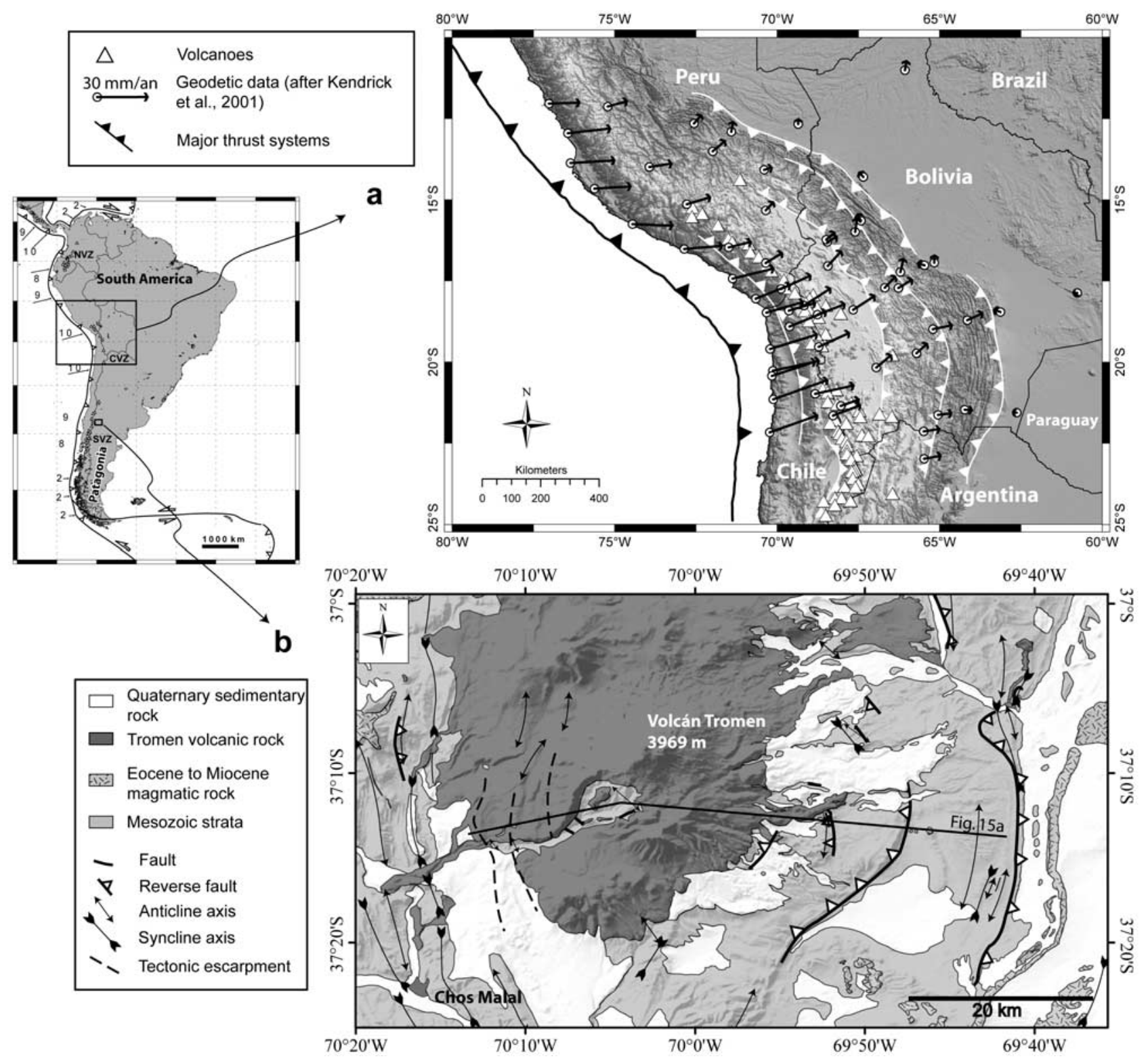

Figure 1. (a) Topographic and structural map of Central Andes. Topographic data are from GTOPO30 database (http://edc.usgs.gov/products/elevation/gtopo30/gtopo30.html). Map locates volcanoes (white triangles), major thrusts, GPS stations (white circles), and corresponding velocity vectors between January 1993 and March 2001 (arrows [after Kendrick et al., 2001]). Data show that Andean margin is shortening. (b) Structural map of Tromen volcano, Neuquén basin, Argentina. Notice arcuate thrusts and folds around Tromen. Both shortening and volcanism are active today. Inset (left) locates both maps [after Galland et al., 2007].

and Tromen, there is good evidence that volcanism and shortening have been coeval [Tibaldi, 2005; Galland et al., 2007].

[6] As long as magma remains molten, it should be very much weaker than its country rock [Rubin, 1993]. We may therefore expect a weak body of magma to influence the pattern of tectonic deformation, as what happens around salt bodies in areas of compression [Ballard et al., 1987; Merle and Vendeville, 1995; Couzens-Schultz et al., 2003; Smit et al., 2003]. For rift systems, it has been suggested that extensional deformation may concentrate around magma reservoirs [Corti et al., 2003]. In orogenic belts, magma may accumulate at the brittle-ductile transition [Watanabe et al., 1999], and so control deformation in the brittle crust [Simancas et al., 2004; Tornos and Casquet, 2005].

[7] In an earlier short publication [Galland et al., 2003], we described the basis of an experimental technique for modeling the possible interactions between tectonic deformation and magmatic intrusion. We also described three preliminary experiments. In a more recent paper [Galland et al., 2006], we described the experimental technique more fully, concentrating on scaling and the properties of model 
Table 1. Model Ratios of Density, Length, Stress, Magma Velocity, and Magma Viscosity [After Galland et al., 2006] ${ }^{\mathrm{a}}$

\begin{tabular}{llllll}
\hline & $\rho^{*}$ & $L^{*}$ & \multicolumn{1}{c}{$\sigma^{*}$} & $\nu^{*}$ & $\eta^{*}$ \\
\hline Upper bound & 0.75 & $10^{-4}$ & $7.5 \times 10^{-5}$ & $10^{-1}$ & $7.5 \times 10^{-6}$ \\
Lower bound & 0.3 & $10^{-5}$ & $4 \times 10^{-6}$ & $10^{-3}$ & $4 \times 10^{-10}$ \\
\hline
\end{tabular}

${ }^{\mathrm{a}}$ Values are upper bounds (top row) and lower bounds (bottom row).

materials. We also briefly described three experiments, comparing them with geological examples from the North Sea, Iceland, and Montana, in various tectonic settings.

[8] In the current manuscript, we describe for the first time more than 20 experiments that are relevant to a compressional setting, analyzing them in detail, and discussing the physical processes that operated. We also compare the experimental results briefly with two natural examples. Our general objective is twofold, (1) to study the mechanisms of magmatic emplacement in a shortening brittle crust and (2) to understand how intrusions modify the pattern of tectonic deformation.

\section{Experimental Procedure}

[9] Each model was representative of processes at a basin scale, so that $1 \mathrm{~cm}$ in the experiment represented $100 \mathrm{~m}$ to $1 \mathrm{~km}$ in nature (Table 1). The scaling of the other parameters and the suitability of the model materials have been described in detail by Galland et al. [2006]. Briefly, we used a fine-grained powder of crystalline silica (SI-CRYSTAL) to represent the brittle crust and a low-viscosity vegetable oil to represent magma (Table 2). The grain size of the silica powder was $\sim 15 \mu \mathrm{m}$. It failed according to a Mohr-Coulomb criterion, its cohesion and angle of internal friction being $\sim 300 \mathrm{~Pa}$ and $\sim 40^{\circ}$, respectively [Galland et al., 2006]. The vegetable oil is produced by Unilever and sold in France under the trademark Végétaline. It is commonly used for cooking. It is solid at room temperature but melts to low-viscosity oil at $\sim 31^{\circ} \mathrm{C}$. At $50^{\circ} \mathrm{C}$, we measured a viscosity of $2 \times 10^{-2} \mathrm{~Pa}$ s (Table 2 ).

[10] Our apparatus was an improved version of earlier ones [Galland et al., 2003; Galland, 2005; Galland et al., 2006]. The models lay in a rectangular box, $60-\mathrm{cm}$ long, $40-\mathrm{cm}$ wide, and 20-cm deep (Figure 2). The model crust consisted of three successive layers of compacted SICRYSTAL powder. Between them, thinner layers of blue sand formed horizontal markers. The multilayer was compacted using a compressed-air vibrator. The total thickness of the multilayer was then $\sim 5.5 \mathrm{~cm}$.

[11] During the experiments, a moving piston caused horizontal shortening within the silica powder (Figure 2), while a pump injected oil at a steady rate through a hole at the base of the box. In nature, magmatic activity commonly follows upon orogenesis. Therefore in the experiments, we allowed some shortening to accumulate before starting the injection. A calibrated pressure gauge recorded the oil pressure within the injection pipe, at a distance of $27 \mathrm{~cm}$ from the base of the model. Over this distance, the estimated pressure drop because of viscous drag was a negligible 6$37 \mathrm{~Pa}$, depending on the rate of injection [Galland, 2005]. The depth of the corresponding column of oil, between the base of the model and the injection point, was $D=15 \pm$ $1 \mathrm{~cm}$. Thus, for an oil density of about $1 \mathrm{~g} \mathrm{~cm}^{-3}$, the pressure at the base of the model was smaller by $1500 \pm 100 \mathrm{~Pa}$ than in the pressure gauge. The estimated error range comes from the fact that the depth $D$ was not accurately recorded. However, the pressure variation during any one experiment was independent of this error. Each experiment lasted for a few minutes (up to a maximum of 22 minutes), after which the oil froze within about half an hour. The model was then cut into longitudinal cross-sections, and the internal structures were photographed.

[12] In nature, crustal thickening may be due to tectonic shortening or magmatic intrusion [Haschke and Günther, 2003]. In our experiments, the piston velocity $v_{\mathrm{p}}$ and the injection rate $Q$ were independent variables. A dimensionless kinematic ratio $R$ expresses their relative rates:

$$
R=\frac{v_{\mathrm{p}} / L_{0}}{Q / V_{\mathrm{m}}}
$$

[13] Here $L_{0}$ and $V_{\mathrm{m}}$ are the initial length and volume of the model, respectively. Thus the value of $R$ reflected the relative rates of shortening versus injection.

\section{Experimental Results}

[14] In all, we did 22 experiments (Table 4). Here we briefly describe the experimental strategy and results, focusing on the main conclusions. The parameters and detailed results of all the experiments are in Appendix A.

[15] We first consider three basic experiments, one with injection only (experiment T1, $R=0$ ), one with shortening only (experiment T2, $R=\infty$ ), and one with injection after shortening (experiment T3; Table 4). Then we describe experiments of variable duration, for which shortening and injection were simultaneous and $R$ was constant (Series C). These experiments provided insights into the main stages of development of internal structures. Finally, we describe the main set of experiments (Series A), for which $R$ varied systematically, from one experiment to the next.

[16] In experiment T1 $(R=0)$, intrusion resulted in an almost axially symmetric body, several millimeters thick. This consisted of a basal sill, branching upward and outward into an oblique cone sheet (Figure 3). The overlying silica powder was uplifted, forming a dome at the free surface. The oil erupted at the edge of the dome. Such features are typical of cone sheets, as observed in the field [e.g., Moreau

Table 2. Mechanical Properties of Model Materials Used in This Study [After Galland et al., 2006]

\begin{tabular}{cccccc}
\hline Material & Behavior & $\begin{array}{c}\text { Density }(\rho), \\
\mathrm{g} \mathrm{cm}^{-3}\end{array}$ & $\begin{array}{c}\text { Cohesion }(C), \\
\mathrm{Pa}\end{array}$ & $\begin{array}{c}\text { Tensile Strength }(T), \\
\mathrm{Pa}\end{array}$ & $\begin{array}{c}\text { Angle of } \\
\text { Internal Friction }(\phi)\end{array}$ \\
\hline $\begin{array}{l}\text { Silica powder } \\
\text { Vegetable oil }\end{array}$ & $\begin{array}{c}\text { Coulomb failure } \\
\text { Newtonian fluid }\end{array}$ & $\approx 1.3$ & $\approx 300$ & $\approx 100$ & $\approx 38$ \\
\hline
\end{tabular}




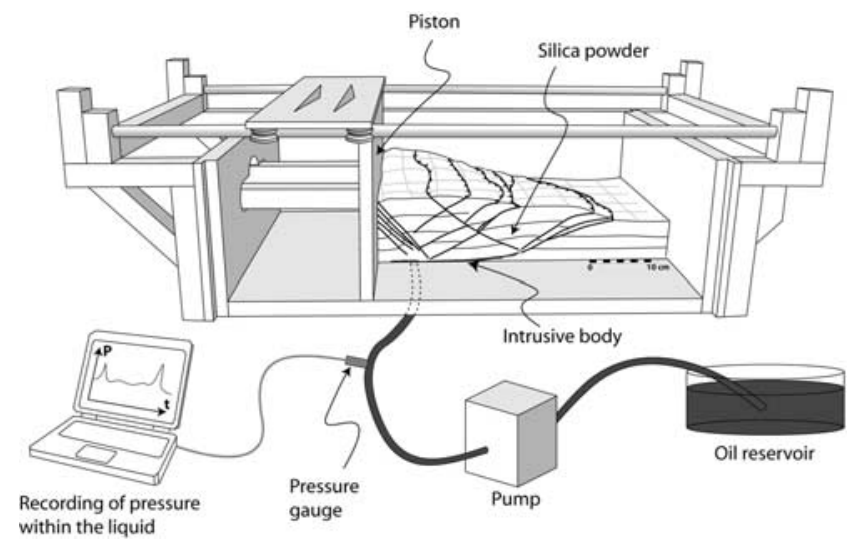

Figure 2. Schematic diagram of experimental apparatus. Mobile piston deforms silica powder. Internal deformation is accommodated by faults that offset horizontal markers within silica powder. During deformation, oil (dark grey) is injected at constant flow rate by pump. Modified after Galland et al. [2006]. et al., 1995; Ancochea et al., 2003] and on seismic profiles [e.g., Hansen and Cartwright, 2006a, 2006b]. In experiment T2 $(R=\infty)$, the shortening resulted in thrust faults, which had straight traces at the free surface (Figure 4). The thrust wedge was similar to those described for models made of quartz sand [Davis et al., 1983; Malavieille, 1984]. In experiment $\mathrm{T} 3$, the oil intruded an already developed thrust wedge. The intrusive body was strongly asymmetric. It consisted of a basal sill, branching laterally and upwards, along thrusts, as an oblique dike (Figure 5).

[17] In Series C, shortening and injection were contemporaneous, and the kinematic ratio had a constant value of $R \approx 22$ (Table 4; Figure 6). In a first stage of shortening only, planar thrusts (RT1 and RT2) formed against the piston. After 5.3\% shortening, injection started. The resulting sill spread along the interface between the silica powder and the basal plate. After a time $t=t_{\mathrm{AT}}$, an arcuate thrust (AT) initiated at the leading edge of the basal sill. The sill stopped spreading and started thickening. The block of silica powder between thrusts RT2 and AT did not deform internally but instead slipped on the basal sill and rose, forming a plateau.

\section{a Exp.T1:injection only}
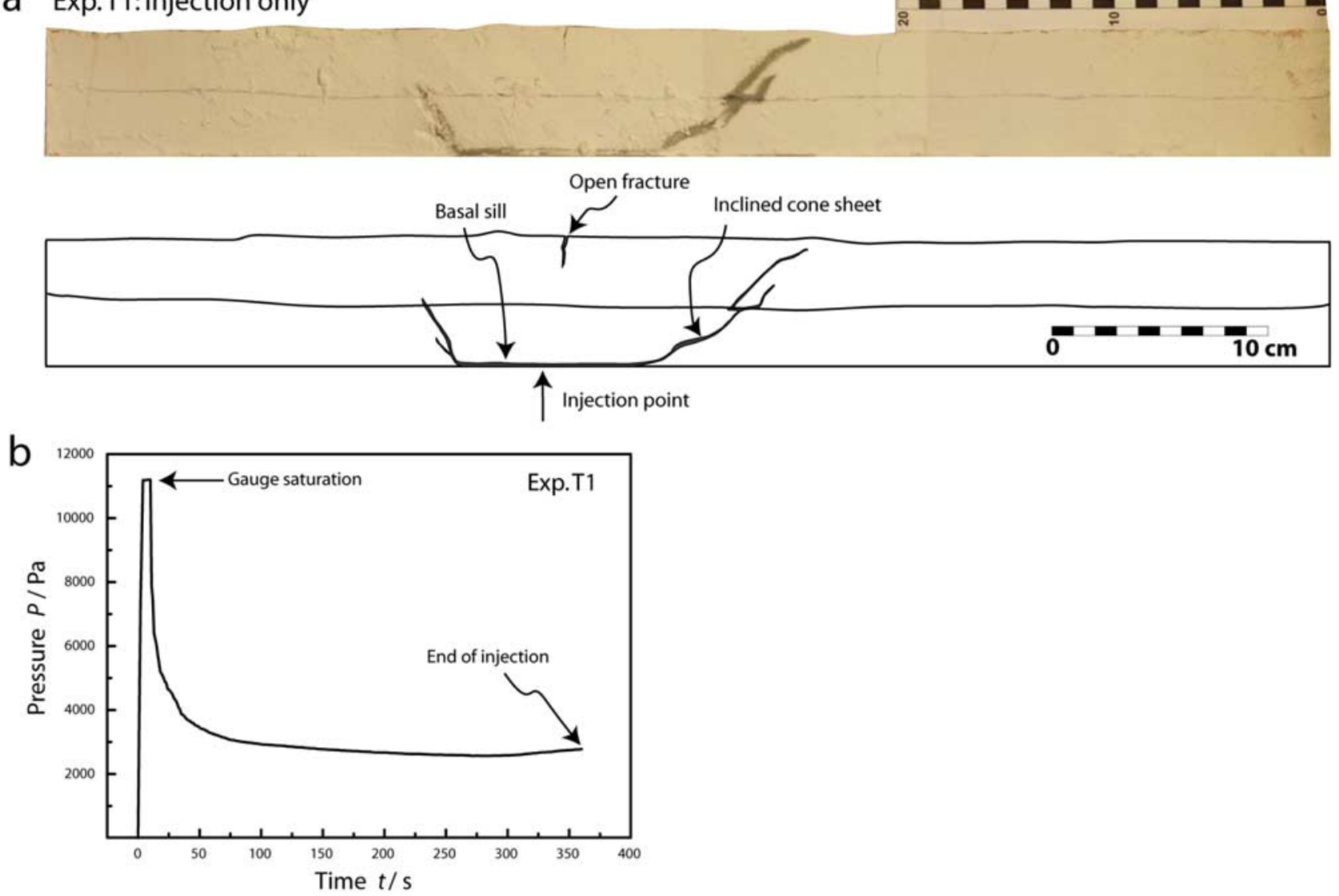

Figure 3. (a) Longitudinal cross sections of experiment $\mathrm{T} 1(R=0)$. Upper section is photograph, lower section is line drawing. Cross sections are central, through injection point. Silica powder has not been shortened. Saucer-shaped intrusive body of oil (dark grey) consists of thin basal sill and peripheral inclined dike. Fraction of oil that percolated a few millimeters through silica powder is not represented. Intruding oil jacked up silica powder, resulting in smooth dome and open cracks at surface. (b) Plot of oil pressure versus time in experiment T1. Initial pressure peak decreased hyperbolically. Toward end of experiment, pressure increased slightly. 

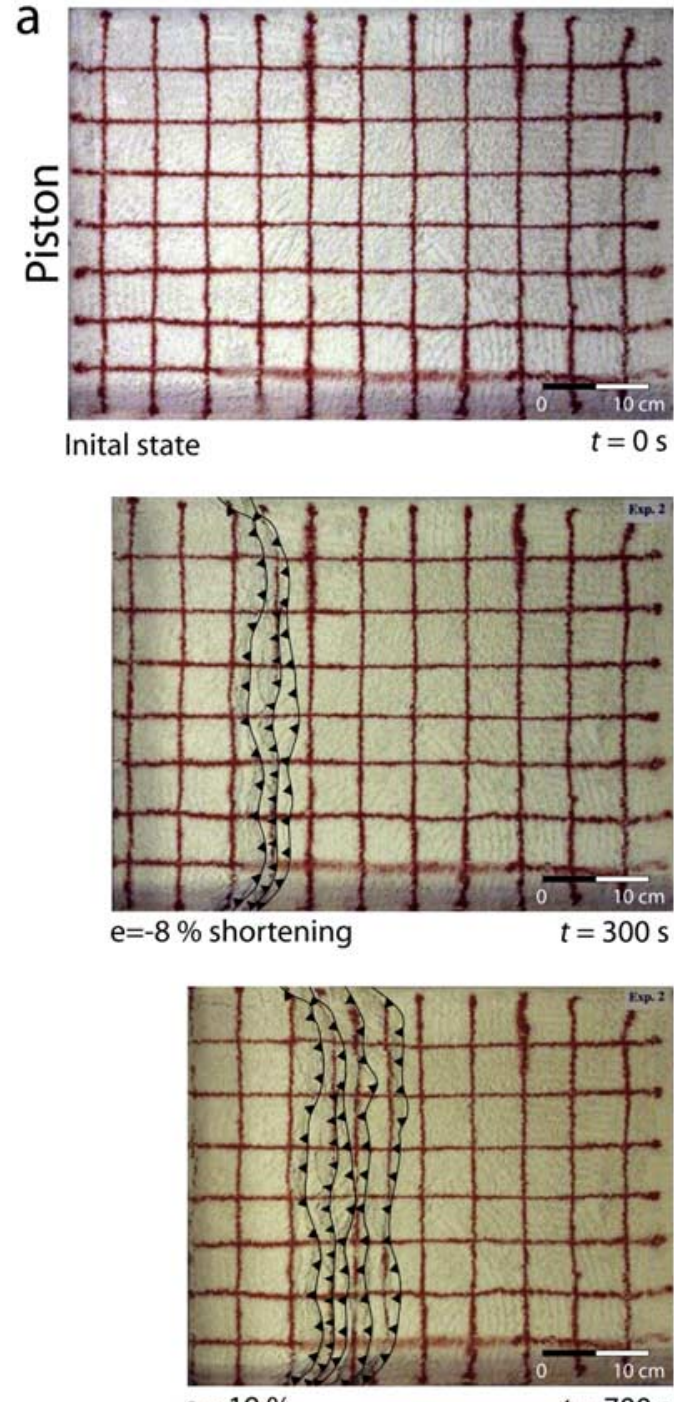

$\mathrm{e}=-19 \%$

$t=700 \mathrm{~s}$

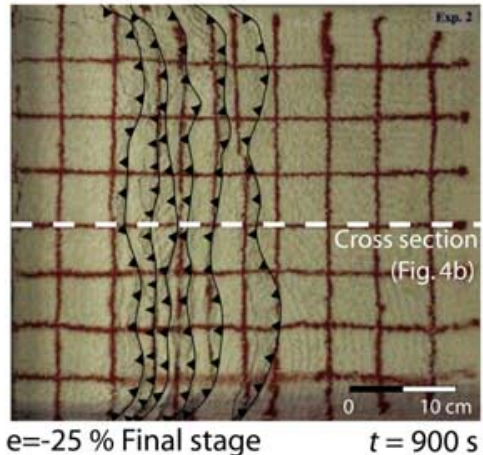

Figure 4. (a) Top views of experiment T2 $(R=\infty)$ at four stages of development (time $t$ in seconds). Piston moved from left to right. Right-verging thrusts had almost straight traces. First thrust formed against piston (left). Later ones formed sequentially (toward right). (b) Cross sections of experiment T2. Upper section is photograph, lower section is line drawing. Surface slope of thrust wedge is $\sim 17^{\circ}$. Interpreted traces of fore-thrusts (dashed lines) are from offsets of horizontal markers (blue or black lines). Forethrusts are regularly spaced. Back thrusts have formed against piston.
[18] Series A consisted of three subseries. In each of them, one parameter was fixed whereas the other one varied (Figure 7). The developing structures were similar to those of Series C. We measured the lengths of the plateau $\left(L_{\mathrm{p}}\right)$ and the basal sill $\left(L_{\mathrm{i}}\right)$, the volume of oil injected when the arcuate thrust formed $\left(V_{0}\right)$, and the surface area of the plateau $\left(S_{\mathrm{p}}\right)$. In general, the plateau length $L_{\mathrm{p}}$ increased together with the injection rate $Q$ and decreased with the piston velocity $v_{\mathrm{p}}$ (Figure 8 ). We obtained similar correlations for parameters $L_{\mathrm{i}}, V_{0}$, and $S_{\mathrm{p}}$ (Table 5). The threedimensional shapes of internal structures were reconstructed by interpolating between serial cross sections (Figure 9). The internal fractures were different, from bottom to top of the model. At the bottom, the fractures were thrust faults (Figures 6 and 7), as one might expect, if the greatest stress were horizontal and the least stress were vertical. In contrast, at the top, the fractures were vertical open cracks, as one might expect in a cohesive material, such as silica powder, if the least stress were horizontal and tensile (Figure 10). Some of the open cracks were parallel to the thrust faults and might have resulted from outer-arc stretching above ramp anticlines. Other open cracks were almost parallel to the overall shortening direction. They concentrated in uplifted zones, against the piston and on top of the plateau (Figure 10). We infer that they resulted from an interaction between the regional compressive stress and topographic highs [Johnson, 1970].

[19] The variation in oil pressure was similar in most of the experiments (Figures 3, 5 and 11). From an initial peak at $\sim 11,000 \mathrm{~Pa}$, the pressure decreased hyperbolically. Such a variation has been observed before, in experiments on fluid injection into soil [Murdoch, 1993, 2002]. However, when arcuate thrusts formed in our experiments, pressure drops were larger and they marked the formation of each thrust (black bars, Figure 11). We infer that there was some mechanical interaction between oil emplacement and arcuate thrusting.

\section{Interpretation and Discussion}

\subsection{Timescales and Length Scales for Magmatic and Tectonic Processes}

[20] In the experiments of series $\mathrm{C}$ and $\mathrm{A}$, shortening and injection at the external boundaries were steady and simultaneous. In contrast, successive faults developed episodically. Was intrusion also an intermittent process? Were the experimental timescales geologically realistic?

[21] In nature, the timescale for the emplacement of a single dike, several meters thick, is of the order of days [e.g., Sigurdsson, 1987]. Resulting volcanic eruptions can last for several years. For the emplacement of a laccolith or a pluton, the timescale is of months [Minakami et al., 1951] to tens of thousands of years [Fialko and Simons, 2001]. In contrast, the timescale for the emplacement of a large batholith or volcano may be 1 Ma or even 10 Ma [Kalakay et al., 2001; Haederle and Atherton, 2002]. Such large objects are usually multiple and composite, having resulted from many smaller and shorter magmatic episodes [Petford, 1996]. A notable example is the Coastal Batholith of Peru [Haederle and Atherton, 2002]. Laccolithic complexes also tend to be composite. The timescale for the emplacement of such complexes is probably about $1 \mathrm{Ma}$, each pulse being 


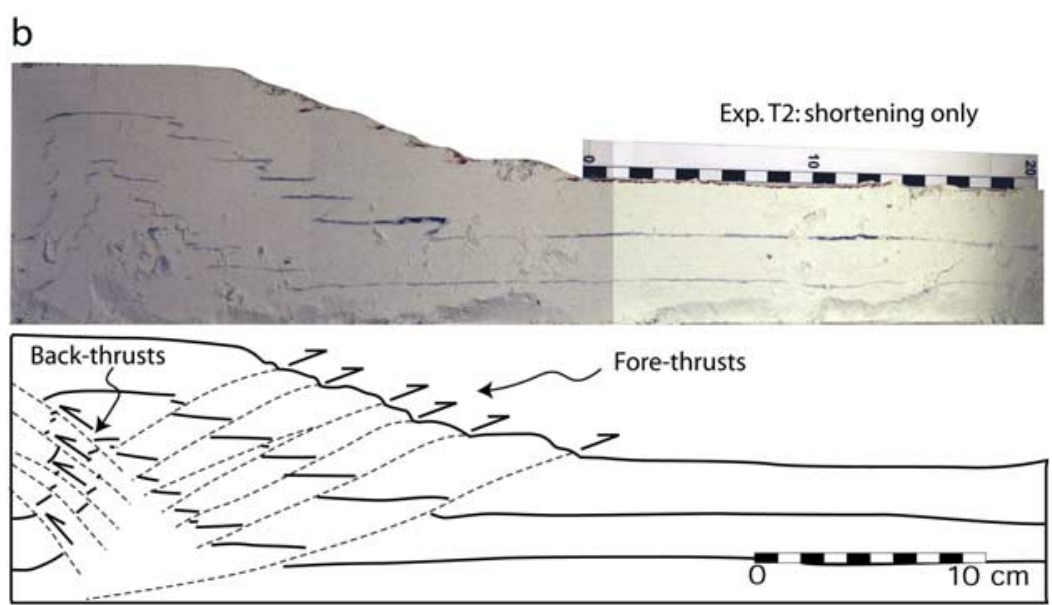

Figure 4. (continued)

a
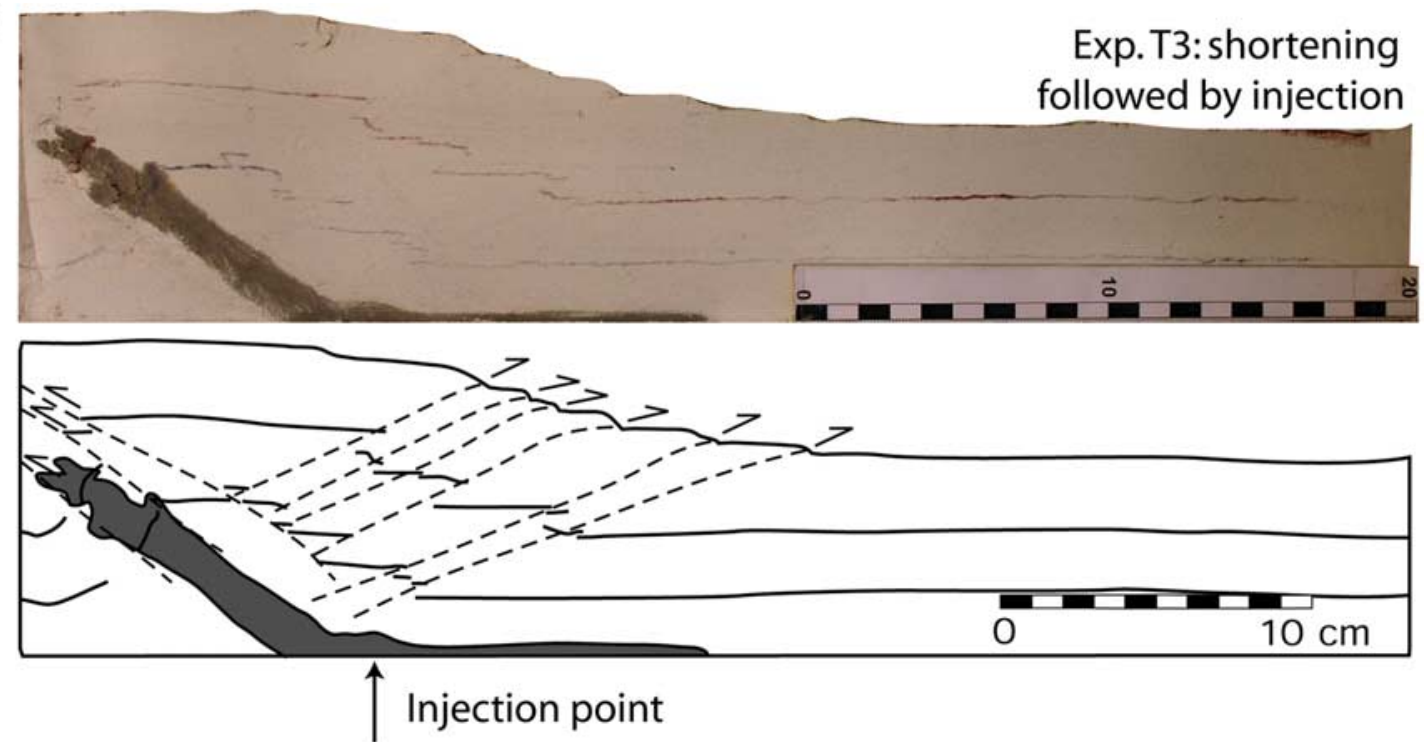

b

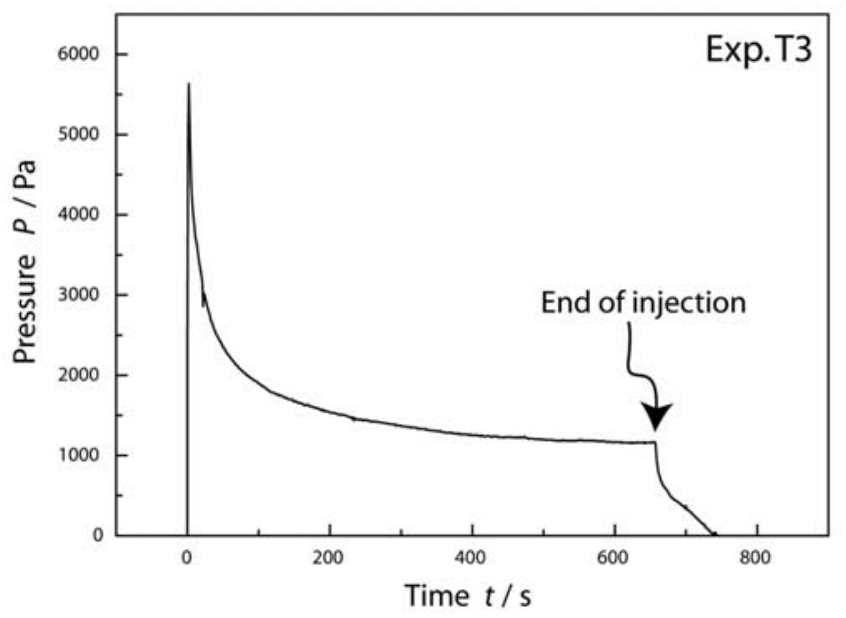

Figure 5. (a) Longitudinal cross sections of experiment $\mathrm{T} 3$ (injection after shortening). Upper section is photograph, lower section is line drawing. Sections are central, through injection point. Thrust wedge resembles that of experiment T2 (Figure 4). Percolation aureole (dark grey) is well developed. Intrusive body consists of thin basal sill and oblique dike along back thrust. Oil has not reached surface. (b) Plot of oil pressure versus time in experiment T3. After initial peak, pressure decreased hyperbolically. 
Cross section

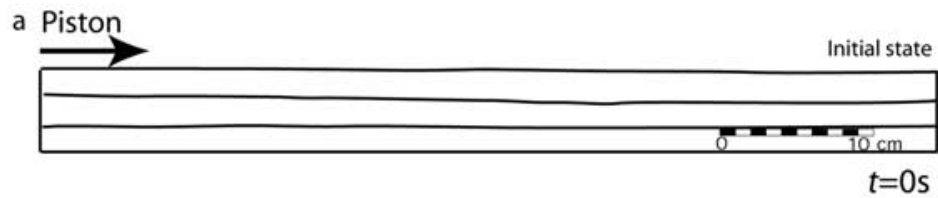

b
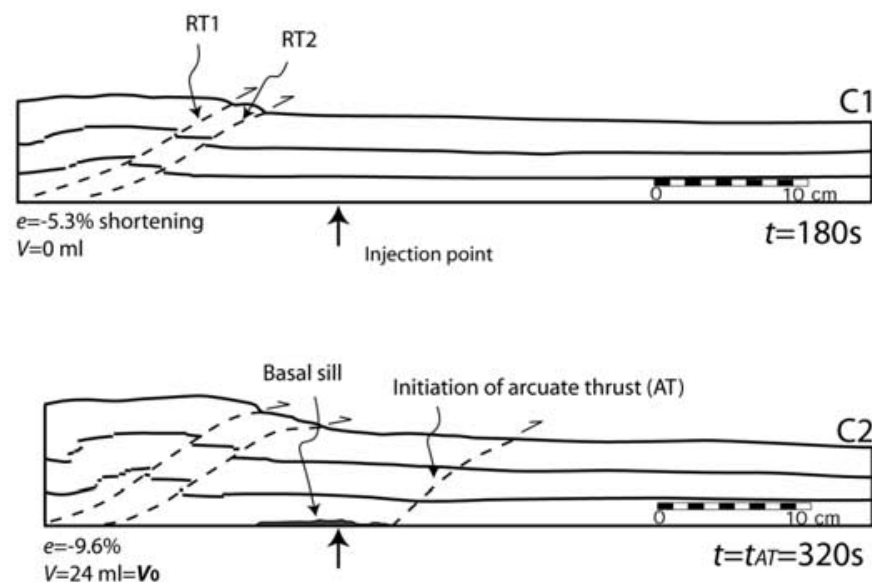

d

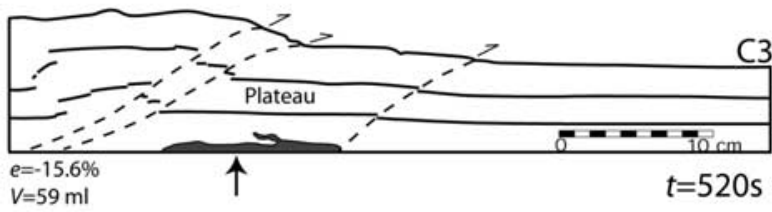

e

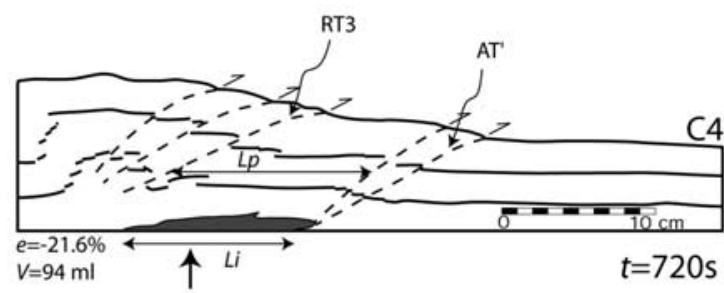

Surface view
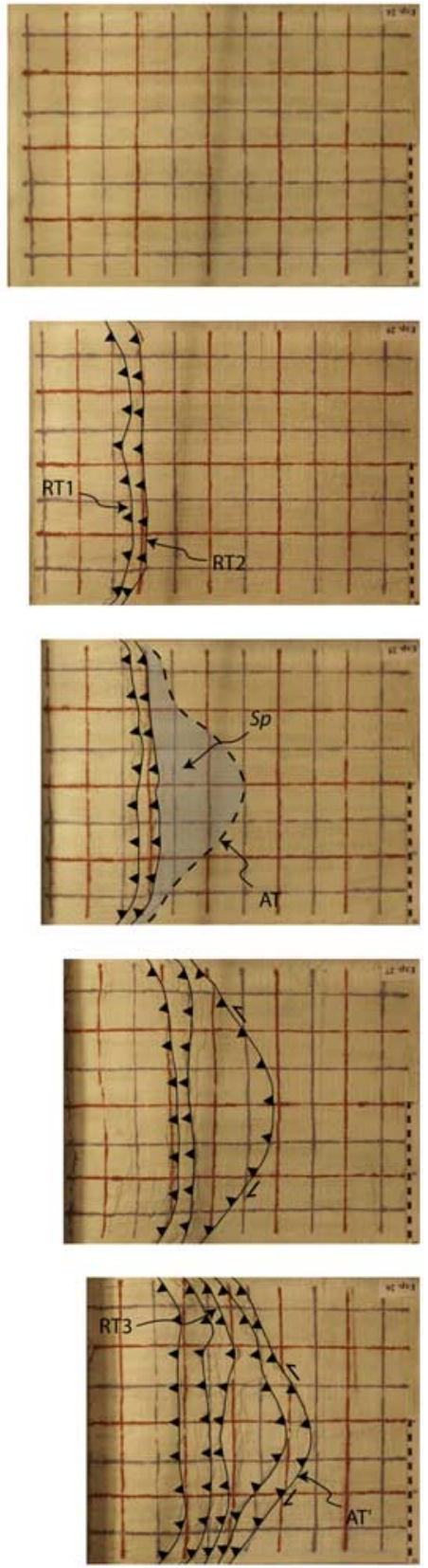

Figure 6. Longitudinal cross sections (left) and corresponding top views (right) for experiments of Series C. Experiments had different durations (in seconds) but same kinematic ratio $(R=22$; Table 4). (a) Initial stage, before deformation and injection. (b) Experiment $\mathrm{C} 1$, after shortening of $e=-5.3 \%$ (at $t=180 \mathrm{~s}$ ) and no injection. Two straight thrusts (RT1 and RT2) formed. Injection started at this stage. (c) Experiment $\mathrm{C} 2$, at $e=-9.6 \%(t=320 \mathrm{~s})$. Oil formed thin basal sill. New thrust (AT; $\left.t=t_{\mathrm{AT}}\right)$ was arcuate and nucleated at leading tip of sill. Plateau initiated between thrusts RT2 and AT. Quantities $V_{0}$ and $S_{\mathrm{p}}$ denote volume of oil injected and surface of plateau at $t=t_{\mathrm{AT}}$. (d) Experiment C3, at $e=$ $-15.6 \%(t=520 \mathrm{~s})$. Deformation concentrated along newest thrust, AT. Below plateau, basal sill lengthened and thickened. (e) Experiment C4, at $e=-21.6 \%(t=720 \mathrm{~s})$. Deformation transferred onto new arcuate thrust, AT'. Plateau uplifted further. Basal sill thickened but did not lengthen. Quantities $L_{\mathrm{i}}$ and $L_{\mathrm{p}}$ denote lengths of basal sill and plateau, respectively.

much shorter than that [Corry, 1988]. In all these examples, the timescale of a magmatic complex is much longer than that of an individual dike or sill. The timescale for the emplacement of an igneous province or for a large com- posite volcano is therefore in the same range as that of tectonic processes. On this basis, our experiments simulate the emplacement of a whole magmatic complex, rather than individual pulses. 


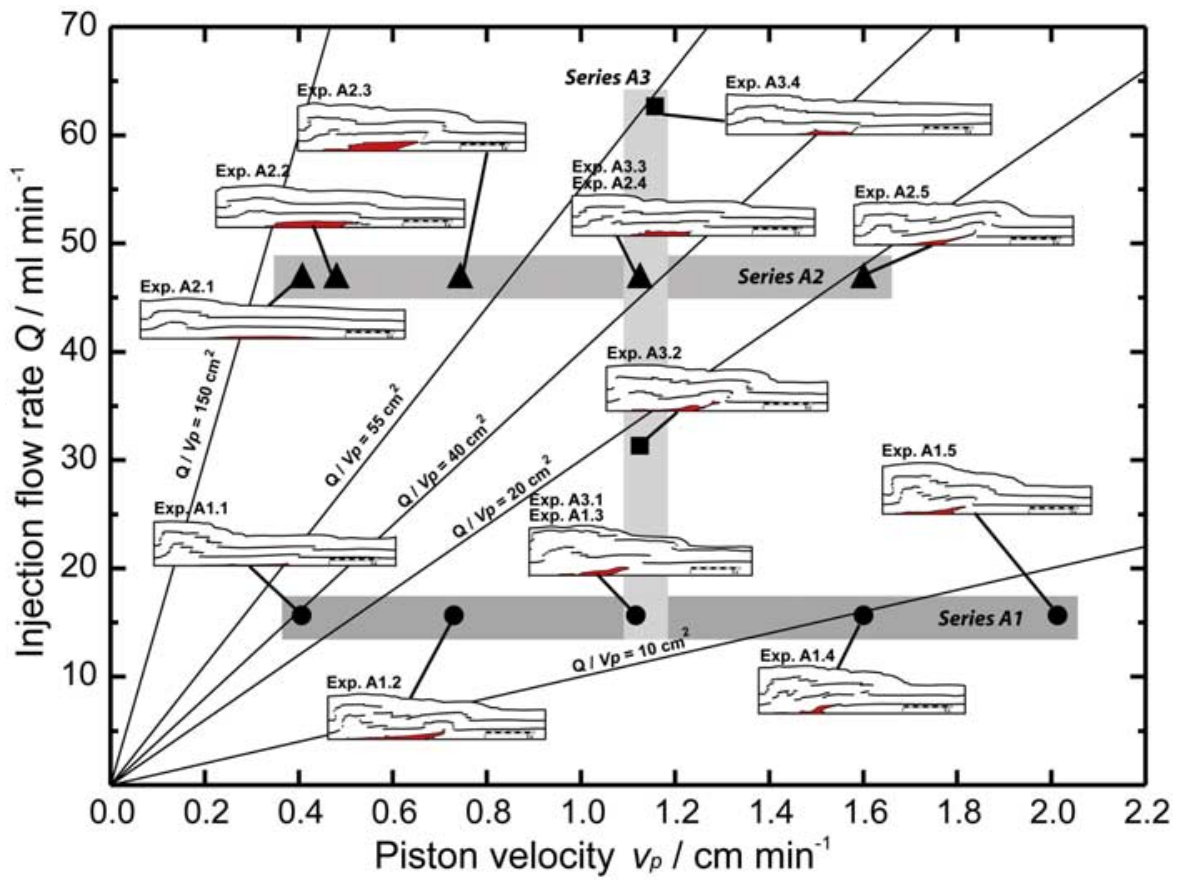

Figure 7. Longitudinal cross sections for Series A on plot of injection rate $Q$ versus piston velocity

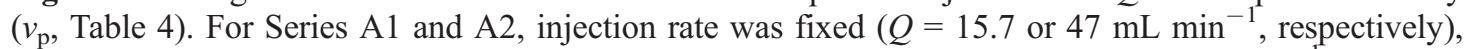
whereas piston velocity differed. For Series A3, piston velocity was fixed $\left(v_{\mathrm{p}}=1.13 \mathrm{~cm} \mathrm{~min}^{-1}\right)$, whereas injection rate differed. Ratio $Q / v_{\mathrm{p}}$ was constant along straight black lines.

[22] Tectonic deformation in the brittle crust is typically episodic and seismic at the scale of individual faults. However, at a larger scale, it is steadier. Thus in experiments, it may be reasonable to impose steady velocities at external boundaries [see e.g., Huiqi et al., 1992; Storti et al., 1997].

[23] In volcanic areas, such as Japan [Fujita et al., 2004], Sicily [Barberi et al., 2000], Alaska [Roman et al., 2004], and Ecuador [Legrand et al., 2002], there is some evidence that episodes of deformation are contemporaneous with crises in magmatic activity. We do not know if this happened in our experiments, because we were not able to observe the structures as they developed. However, we suspect that it was the case.

[24] The thickness of the intrusive body in the experiments is typically of the order of $1 \mathrm{~cm}$. As we were modeling processes at a basin scale, the length ratio between model and nature was between $10^{5}$ and $10^{-4}$ [Galland et al., 2006]. Therefore the thickness of equivalent bodies in nature was between $100 \mathrm{~m}$ and $1 \mathrm{~km}$, which is typical of a magmatic complex. As in our experiments, so in nature, such bodies may greatly influence the stress state of their host [Vigneresse et al., 1999; González and Aragón, 2000].

[25] In summary, we believe that our assumption of steady velocities and rates of intrusion were reasonable first approximations to what happens at a large scale in nature.

\subsection{Mechanisms of Oil Emplacement}

[26] In nature, the shape of an intrusive body reflects its emplacement mechanism [e.g., Rubin, 1993; Moyen et al., 2001]. Sheet-like intrusive bodies, such as dikes and sills, appear to result from hydraulic fracturing [Hubbert and
Willis, 1957; Lister and Kerr, 1991; Clemens and Mawer, 1992; Rubin, 1995b].

[27] In experiment $\mathrm{T} 1$ (injection only), the intrusive body was a thin saucer-shaped sill. Its aspect ratio of thickness to length $\left(w / L_{\mathrm{i}}\right)$ was about $10^{-2}$ (Figure $3 \mathrm{a}$ ). In experiments of Series $C$, the basal sill initially had an aspect ratio of the same order of magnitude (Figure 5a). Such aspect ratios are characteristic of dikes and sills in nature [Rubin, 1993, 1995a] and are typical of hydraulic fracturing.

[28] Although for large strains, granular materials tend to yield according to a Coulomb criterion; for small strains, the relationship between stress and strain is almost linear [Mandl et al., 1977]. In our experiments, the oil intrusion resulted in strains that were much smaller than the horizontal shortening imposed by the piston. To account for small strains and linear behavior, elastic models are the simplest and the best known. They have been used to study hydraulic fracturing in various media, including granular materials [Murdoch, 1993, 2002]. According to the elastic theory [e.g., Pollard, 1987], the aspect ratio of a hydraulic fracture in an infinite homogeneous medium is given by:

$$
\frac{w}{L_{\mathrm{i}}}=\frac{\left(P-\sigma_{\mathrm{n}}\right)}{\mu /(1-\nu)} \equiv \frac{\Delta P}{M}
$$

Here $\sigma_{\mathrm{n}}$ is the stress acting normally to the fracture, $\Delta P$ is the fluid overpressure within the fracture, and $\mu$ and $\nu$ are the shear modulus and Poisson's ratio of the country rock. For dikes in nature, equation (2) yields estimates of magma overpressure between 1 and $10 \mathrm{MPa}$ [Rubin and Pollard, 1987].

[29] In our experiments, variations in oil pressure provided constraints on the emplacement mechanism of the intrusive 

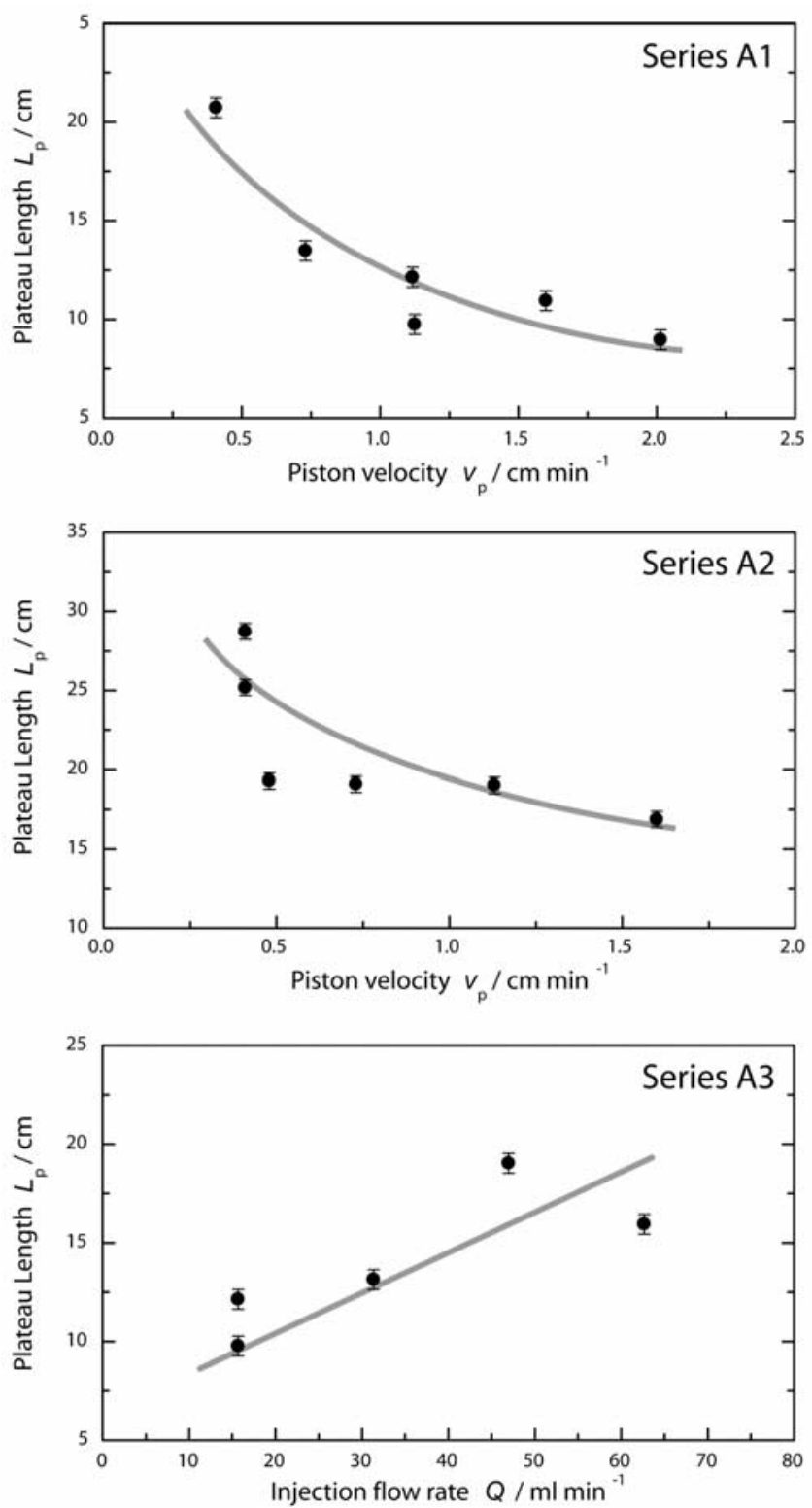

Figure 8. Plots of plateau length $\left(L_{\mathrm{p}}\right)$ versus piston velocity $\left(v_{\mathrm{p}}\right)$ for Series (a) A1 or (b) A2, and versus injection flow rate $(Q)$ for Series A3. Curves (grey) highlight trends.

body. Hyperbolic variations in fluid pressure have been observed during experiments on fluid injection into soil [Murdoch, 1993, 2002]. In those studies, a theoretical analysis of pressure variation, on the basis of an elastic model, fitted the data well. Here we use a simpler physical analysis, also on the basis of an elastic model, to explain the observed pressure drops. In our experiments, the total volume of intruding oil was $V=Q t$. For a circular horizontal sill of uniform thickness, the volume is $V \approx w \pi L_{\mathrm{i}}^{2} / 4$. According to these expressions and to equation (2), the time elapsed is proportional to the overpressure and to the cube of the fracture length:

$$
t \propto \Delta P L_{\mathrm{i}}^{3}
$$

[30] A hydraulic fracture propagates when the stress around the fracture tip exceeds the failure strength of the country rock [e.g., Pollard, 1987]. Various models based on fracture mechanics have been used as criteria for fracture propagation [e.g., Inglis, 1913; Griffith, 1921, 1924; Irwin, 1958]. In all of them, the overpressure $\Delta P$ of an intruding fluid, as required to propagate a fracture within an elastic medium, is inversely proportional to the square root of its length, so that:

$$
\Delta P \propto L_{\mathrm{i}}^{-1 / 2}
$$

From equations (3) and (4), the overpressure $\Delta P$ should vary as follows:

$$
\Delta P \propto t^{-1 / 5}
$$

After an infinitely long time, no overpressure should be necessary for further propagation. Instead, the fracture should open if the fluid pressure exceeds the normal stress

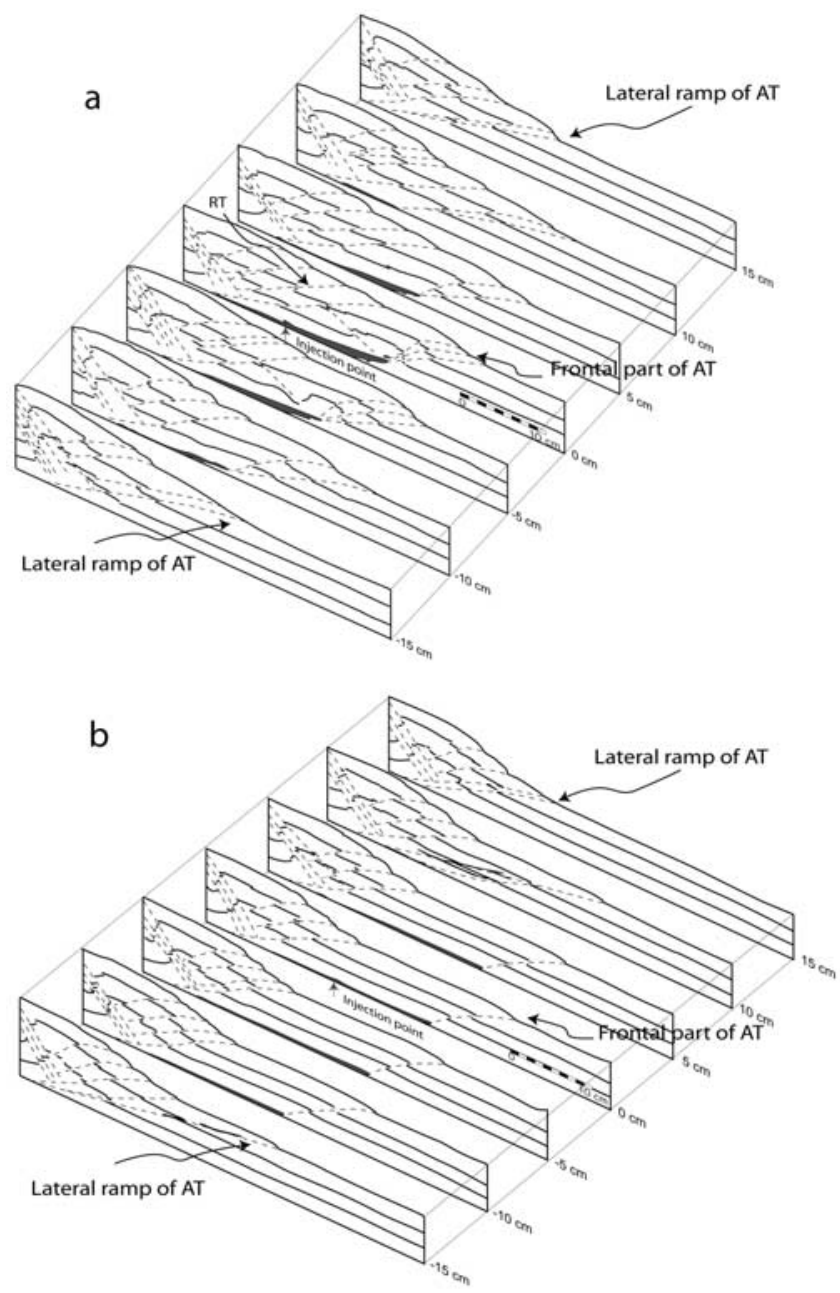

Figure 9. Serial cross sections of experiment (a) A1.2 and (b) A1.1 Datum $(0 \mathrm{~cm})$ was injection point. Distance between cross sections was $5 \mathrm{~cm}$. In both experiments, distance between straight thrust RT and arcuate thrust AT decreased from center to sides; intrusive body was almost circular in plan view; and sill was almost as long as plateau. In experiment A1.2, oil intruded and rose along lateral ramps of AT; in A1.1, it did not. 


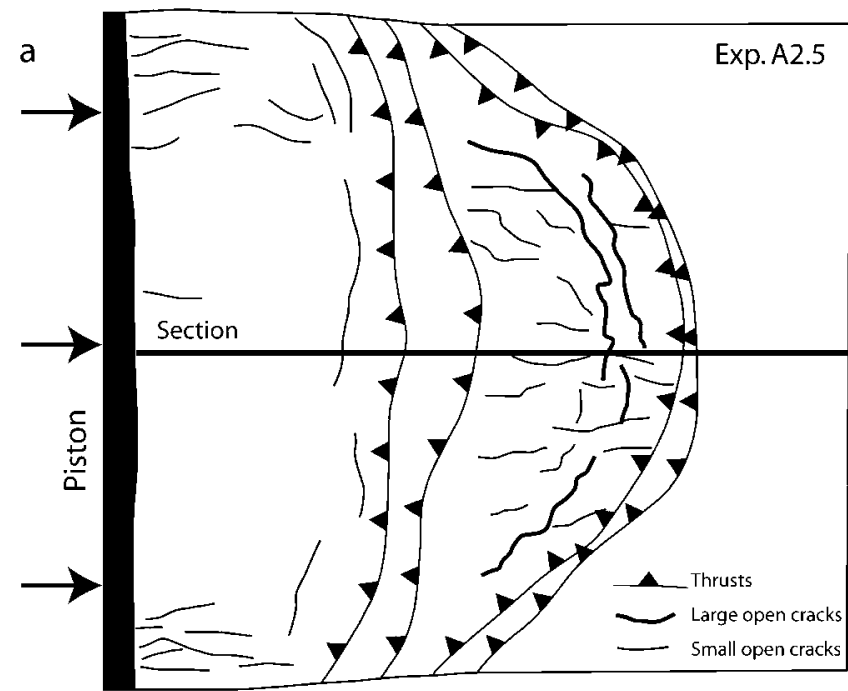

b

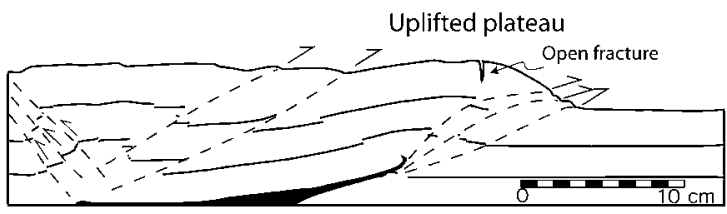

Figure 10. Fracture pattern of experiment A2.5. (a) Line drawing of surface shows thrust traces and open cracks. Some open cracks are parallel to thrust traces; others, against piston and on top of uplifted plateau, are parallel to shortening direction. Straight line locates central section. (b) Central section of experiment A2.5, showing thrust traces (dashed lines). Plateau above arcuate thrust has been uplifted.

$\sigma_{\mathrm{n}}$. Therefore the fluid pressure required to propagate a fracture becomes:

$$
P=A t^{-1 / 5}+\sigma_{\mathrm{n}}
$$

[31] Here $A$ is a constant, having dimensions of $\mathrm{Pa} \mathrm{s}^{1 / 5}$. According to equation (6), the longer the crack, the more easily it propagates.

[32] In most of our experiments, the readings of residual pressure were between 2000 and $2500 \mathrm{~Pa}$ (Figures 3 and 11). Because the pressure measurements were made at an oil depth of $D=15 \pm 1 \mathrm{~cm}$ beneath the base of the model, the residual pressure in the sill was between 400 and $1100 \mathrm{~Pa}$. That range covers an independent estimate of lithostatic pressure, $715 \mathrm{~Pa}$, which comes from taking a model thickness of $5.5 \mathrm{~cm}$ and a density of silica powder of $1.3 \mathrm{~g} \mathrm{~cm}^{3}$. Thus the pressure in the sill decreased to approximately lithostatic values, as would be expected for a long fracture (equation 6). However, the initial pressure was very much higher, as would be expected for a short fracture.

[33] To the pressure variations in our experiments, we fitted an inverse power law (hyperbolic function) of exponent $d$ (Table 3 ). The data range was between the initial peak and the first episodic drop in pressure (see section 3; Figure 11). For experiments A1.3, A1.4, and A3.4, the data ranges were short and the fits were not good. For the other experiments, the fits were acceptable and the estimates of $d$ were between $-0.15 \pm 0.15$ and $-1.56 \pm 0.2$ (Table 3 ).
Most of these estimates were significantly smaller than the theoretical value of $d=-1 / 5$ (equation 6).

[34] The difference between theory and observation may have come from the choice of fracture criterion. Equation (4) is valid for the mathematically simple case of a crack in an infinite homogeneous elastic medium (see review in Pollard [1987]). However, in our experiments, the host material was not of infinite extent. Instead, it had (1) an upper boundary, which was free, and (2) a lower boundary, between soft silica powder and strong basal plate. The sill initially spread along the lower boundary (Figures 3, 5, 6, and 7). As it did so, the oil under pressure jacked up the overriding silica powder, doming the free upper surface of the model. In the experiments, this effect is more pronounced than it is for theories of a crack in an infinite medium. For more refined theories that take into account a free surface, the fracture criterion depends upon the depth of the fracture beneath that surface [e.g., Pollard and Holzhausen, 1979; Fialko, 2001; Rivalta and Dahm, 2006]. If in addition the fracture is horizontal and against a rigid basement, the fluid pressure decreases hyperbolically with time and has an exponent of -0.5 [Murdoch, 2002]. This value is in good agreement with the exponents that we fitted to our data (Table 3). We therefore suspect that the model of a horizontal crack beneath a free surface and against a rigid basement is especially relevant to our experiments.

[35] In nature, sills and laccoliths tend to form at the interface between a sedimentary cover and its less deformable basement [e.g., Gilbert, 1877]. Similarly, in our experiments, we observed that sills formed preferentially at the interface between the silica powder and the basal plate. Probably, the interface was weaker in tension than the silica powder itself, but we were not able to measure this effect.

[36] The tensile strength of fractured rock is smaller than that of homogeneous rock because faults and fractures tend to have small cohesion [Schellart, 2000; Sibson, 2003]. The pressure required for magma to intrude a preexisting fracture should therefore be smaller than that required to open a new fracture. The same is true for granular materials, such as sand [Krantz, 1991]. That may explain why, in experiment T3, the oil intruded along preexisting thrusts.

\subsection{Interactions Between Shortening and Intrusion 4.3.1. Influence of Horizontal Compression on Oil Emplacement}

[37] In the brittle crust, dikes would appear to form in orientations that are perpendicular to the least principal stress, $\sigma_{3}$, and parallel to the greatest principal stress, $\sigma_{1}$ [Hubbert and Willis, 1957]. Did this happen in our experiments?

[38] In experiment T1 (Figure 3), no external stress was applied to the silica powder. Instead, the overpressure within the intrusive body appeared to have induced a local stress field, axially symmetric about the injection point [Phillips, 1974; Gudmundsson, 1998; Gray and Monaghan, 2004]. The overpressured oil jacked up the overlying silica powder, resulting in a smooth dome at the surface. We infer that, at the edges of the dome, differential uplift resulted in annular shear stresses, and so in the rotation of the principal stresses. Therefore $\sigma_{1}$ became oblique to the horizontal, and hydraulic fractures propagated as inclined sheets, resulting 

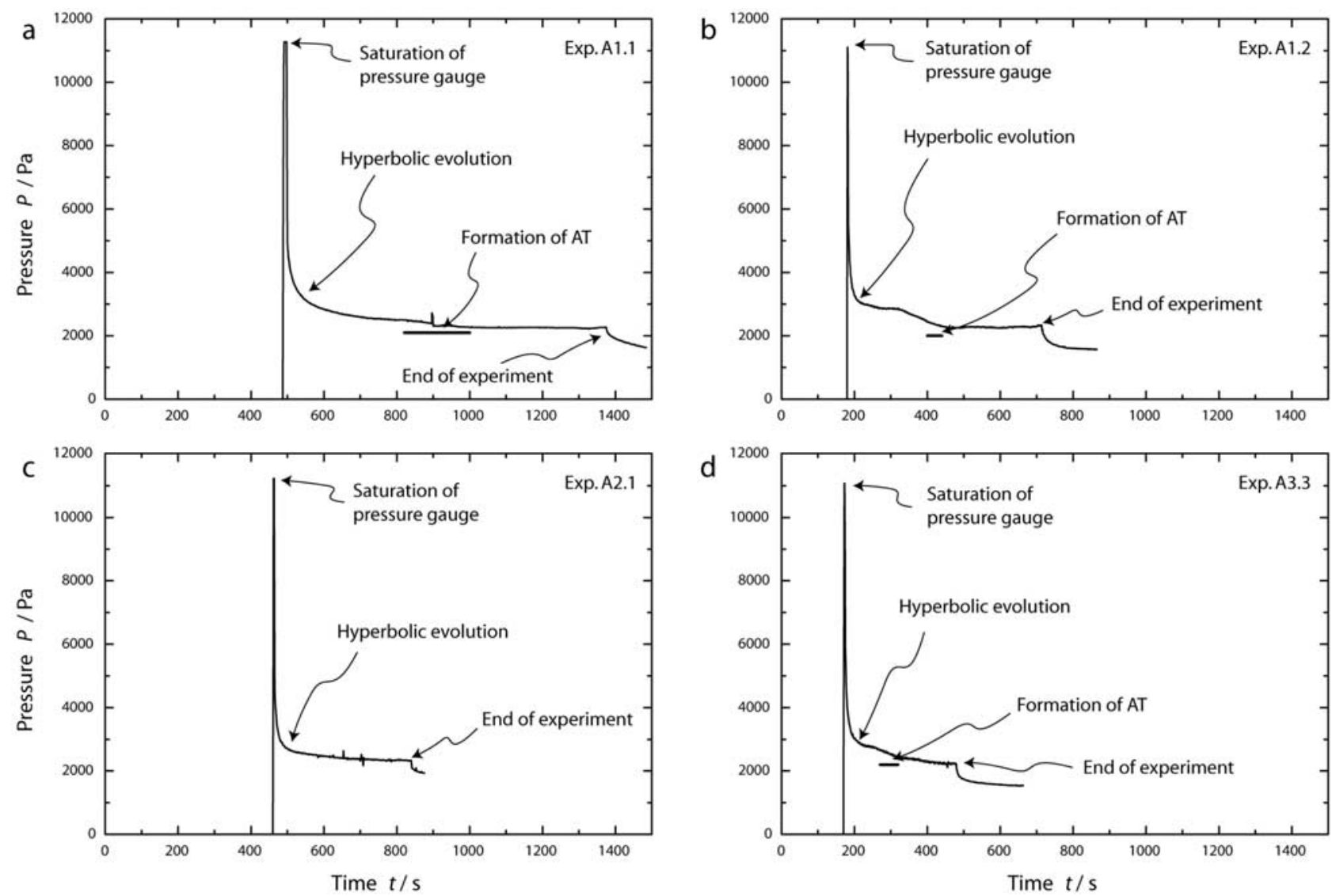

Figure 11. Plots of oil pressure versus time for experiments (a) A1.1, (b) A1.2, (c) A2.1, and (d) A3.3. In experiment A2.1, deformation did not interact with intrusive oil, and pressure decreased hyperbolically, as in experiments T1 and T3. In other experiments, arcuate thrust interacted with intrusive oil, and pressure variation was more complex. After the first period of hyperbolic decrease, more rapid pressure drop coincided with the formation of arcuate thrust, AT. Thereafter, pressure remained almost constant.

in saucer-shaped sills (Figure 3 [Malthe-Sørenssen et al., 2004; Galland et al., 2006]).

[39] In contrast, in the experiments of series $\mathrm{C}$ and $\mathrm{A}$, the mobile piston presumably induced a regional stress field, in which the greatest stress $\sigma_{1}$ was close to horizontal, and the least stress $\sigma_{3}$ was close to vertical. In such a setting, according to theory, hydraulic fractures should be horizontal [Hubbert and Willis, 1957]. Our experimental results for Series $\mathrm{C}$ and $\mathrm{A}$ seem to follow this theory. In every experiment, the oil formed a horizontal sill at the base of the silica powder (Figure 7). Although the mechanical interface between the silica powder and the basal plate strongly controlled oil emplacement (see section 4.2), the basal sills in these experiments were much longer (up to $30 \mathrm{~cm}$ for experiment A2.1; Figure 7) than they were in experiments T1 and T3 ( $\sim 10 \mathrm{~cm}$; Figures 3 and 5$)$. We infer that horizontal compression was favorable to the development of sills.

[40] In the initial stages of most of our experiments, the basal sill simultaneously thickened and lengthened (Figure 6). This is typical of hydraulic fracturing [Pollard, 1987]. However, after an arcuate thrust formed at its leading edge, the basal sill no longer lengthened, although it did thicken. Thus the mechanism appears to have changed, from hydraulic fracturing, to one controlled by thrusting. Additional evidence for this comes from the records of oil pressure (Figure 11). The early hyperbolic decrease in pressure is to be expected for progressive hydraulic fracturing (see section 4.2). In contrast, the later episodic drops in pressure, as each arcuate thrust initiated, argue for another mechanism. We suspect that late thickening of the basal sill was a passive response to uplift of the overlying plateau, which resulted from thrusting. In other words, uplift of the plateau controlled the emplacement and accumulation of oil at depth.

\subsubsection{Influence of Intrusive Body on Further Deformation}

[41] In our experiments, the overall shape of the thrust wedge and the distribution of internal structures depended on whether or not oil was injected. In experiment T2, where no oil was injected, the resulting thrust wedge was similar to that obtained in models made of quartz sand [Davis et al., 1983; Malavieille, 1984; Dahlen, 1990; Huiqi et al., 1992]. Thus the wedge had a large apical angle, the internal thrust faults were planar, and they were regularly and narrowly spaced (Figure 4). In contrast, in the experiments where oil was injected, the apical angle of the thrust wedge was much smaller, the last thrusts to form had arcuate traces (Figure 6), and the spacing between these and the earlier planar forethrusts was much greater (Table 5). 
Table 3. Experimental Parameters ${ }^{\mathrm{a}}$

\begin{tabular}{llcllllll}
\hline & $v_{\mathrm{p}}, \mathrm{cm} \mathrm{min}^{-1}$ & $Q, \mathrm{~mL} \mathrm{~min}^{-1}$ & $R$ & $\mathrm{e}_{\mathrm{i}}$ & $\mathrm{e}$ & $\mathrm{t}_{\text {exp }}, \mathrm{s}$ & $t_{\text {ini }}, \mathrm{s}$ & $V_{\mathrm{I}}, \mathrm{mL}$ \\
\hline T1 & 0 & 15.7 & 0 & 0 & 0 & 360 & 360 & 94 \\
T2 & 0.96 & 0.0 & $\infty$ & -24.7 & -24.7 & 900 & 0 & 0 \\
T3 & 1.21 & 20.9 & $\infty, 0$ & -22.8 & -22.8 & 1320 & 660 & 230 \\
Series C & & & & & & & & \\
C1 & 1.03 & 10.4 & 21.8 & -5.3 & -5.3 & 180 & 0 & 0 \\
C2 & 1.05 & 10.4 & 22.1 & -5.3 & -9.6 & 320 & 140 & 24 \\
C3 & 1.05 & 10.4 & 22.1 & -5.3 & -15.6 & 520 & 340 & 59 \\
C4 & 1.06 & 10.4 & 22.3 & -5.3 & -21.8 & 720 & 540 & 94 \\
Series A1 & & & & & & & & \\
A1.1 & 0.41 & 15.7 & 5.7 & -5.3 & -15.8 & 1360 & 880 & 230 \\
A1.2 & 0.73 & 15.7 & 10.2 & -5.3 & -24.2 & 1160 & 900 & 235 \\
A1.3 & 1.12 & 15.7 & 15.7 & -5.3 & -23.0 & 720 & 540 & 141 \\
A1.3 bis & 1.13 & 15.7 & 13.3 & -5.3 & -14.0 & 520 & 330 & 86 \\
A1.4 & 1.60 & 15.7 & 22.5 & -5.3 & -27.5 & 600 & 480 & 125 \\
A1.5 & 2.01 & 15.7 & 28.3 & -5.3 & -25.9 & 450 & 360 & 94 \\
Series A2 & & & & & & & & \\
A2.1 & 0.41 & 47.0 & 1.9 & -5.3 & -9.8 & 840 & 380 & 298 \\
A2.1 bis & 0.41 & 47.0 & 1.9 & -5.3 & -11.9 & 1020 & 540 & 423 \\
A2.2 & 0.48 & 47.0 & 2.2 & -5.3 & -12.4 & 900 & 520 & 407 \\
A2.3 & 0.73 & 47.0 & 3.4 & -5.3 & -19.9 & 960 & 700 & 548 \\
A2.4 & 1.13 & 47.0 & 5.3 & -5.3 & -15.5 & 480 & 310 & 243 \\
A2.5 & 1.60 & 47.0 & 7.5 & -5.3 & -24.7 & 540 & 420 & 329 \\
Series A3 & & & & & & & & \\
A3.1 (=A1.3) & 1.12 & 15.7 & 15.7 & -5.3 & -23.0 & 720 & 540 & 141 \\
A3.1 bis (=A1.3 bis) & 1.13 & 15.7 & 13.3 & -5.3 & -14.0 & 520 & 330 & 86 \\
A3.2 & 1.13 & 31.3 & 7.9 & -5.3 & -23.2 & 720 & 550 & 287 \\
A3.3 & 1.13 & 47.0 & 5.3 & -5.3 & -15.5 & 480 & 310 & 243 \\
A3.4 & 1.16 & 62.7 & 4.1 & -5.3 & -9.3 & 280 & 110 & 115 \\
\hline & & & & & & & &
\end{tabular}

${ }^{\mathrm{a}}$ For symbols, see Table A1.

[42] According to theoretical and experimental studies, the surface slope of a thrust wedge depends on (1) the cohesion $C$ and angle of internal friction $\phi$ of the deforming material, (2) the basal slope $\beta$, and (3) the friction coefficient at the base [Davis et al., 1983; Dahlen, 1990; Huiqi et al., 1992; Smit et al., 2003]. In our experiments, $C, \phi$, and $\beta$ were constant, so that the relatively small values of $\alpha$ in the experiments of Series A should have resulted from small basal friction. We infer that the sill lubricated the base of the wedge, providing a detachment and resulting in a weakly deformed overlying plateau [Smit et al., 2003].

[43] That the latest thrust was arcuate was probably another consequence of the lubricating properties of the basal sill. In each experiment, the arcuate thrust closely followed the curved edge of the basal sill, this curvature being because of injection at a point (Figure 12). Because the upper surface of the wedge was flat, when the latest thrust formed, its arcuate shape could not have resulted from a topographic high, as in the experiments of Marques and Cobbold [2001, 2002, 2006]. Furthermore, the arcuate shape did not result from friction at the sidewalls of the box, as this effect was small in the experiments with no injection. We conclude that the structures, in the experiments where oil was injected, resulted from mechanical interaction between the soft intrusive bodies and the applied shortening. We may expect similar interactions to occur in nature.

\subsubsection{Influence of Kinematic Ratio $R$ on Shape and Structure of the Wedge}

[44] The kinematic ratio $\boldsymbol{R}$ links the experimental parameters $v_{\mathrm{p}}$ and $Q$ and expresses the relative rates of tectonic shortening and intrusion.
[45] In Series A, $R$ was different from one experiment to another. Its value was between 1.91 and 28.3 (Tables 4 and 5). The lengths of the basal sill and plateau depended on the value of $R$. We plotted the lengths in the form of dimensionless ratios, in other words, aspect ratios (Figure 13). The ratio $L_{\mathrm{i}} / h$ was smaller, when $R$ was greater (Figure 13a). A hyperbolic function of exponent $b=-0.41 \pm 0.07$ fitted the data well. The ratio $L_{\mathrm{p}} / h$ followed a similar hyperbolic trend (Figure 13b), and the exponent was $b=-0.36 \pm 0.05$. However, the ratio $V_{0} / h^{3}$ was inversely proportional to $R$ (Figure 13d). Thus the greater was the rate of tectonic thickening, relative to intrusion, the shorter were the intrusive body and the plateau.

[46] As mentioned previously (see section 4.3.2), the outline of the basal sill at $t=t_{\mathrm{AT}}$ controlled the location and shape of arcuate thrusts. During the course of an experiment, the in situ shape of the intrusive body was unknown, but its volume increased linearly with time, $V(t)=Q t$. From equation (1), we may calculate an expression for $V(t)$ as a function of $v_{\mathrm{p}}$ and $R$ :

$$
V(t)=\frac{\nu_{\mathrm{p}} / L_{0}}{R / V_{\mathrm{m}}} t
$$

Here $v_{\mathrm{p}}, L_{0}, R$, and $V_{\mathrm{m}}$ are all constant. At $t=t_{\mathrm{AT}}$, the volume injected is $V_{0}$. By integration of $v_{\mathrm{p}} / L_{0}$, the amount of shortening $e_{\mathrm{AT}}$ is:

$$
-e_{\mathrm{AT}}=\frac{t_{\mathrm{AT}} \nu_{\mathrm{p}}}{L_{0}}
$$

[47] In our experiments, $e_{\mathrm{AT}}$ was almost constant for all values of $R$, having a mean critical value of $e_{\mathrm{ATC}} \approx-0.1$ 
a
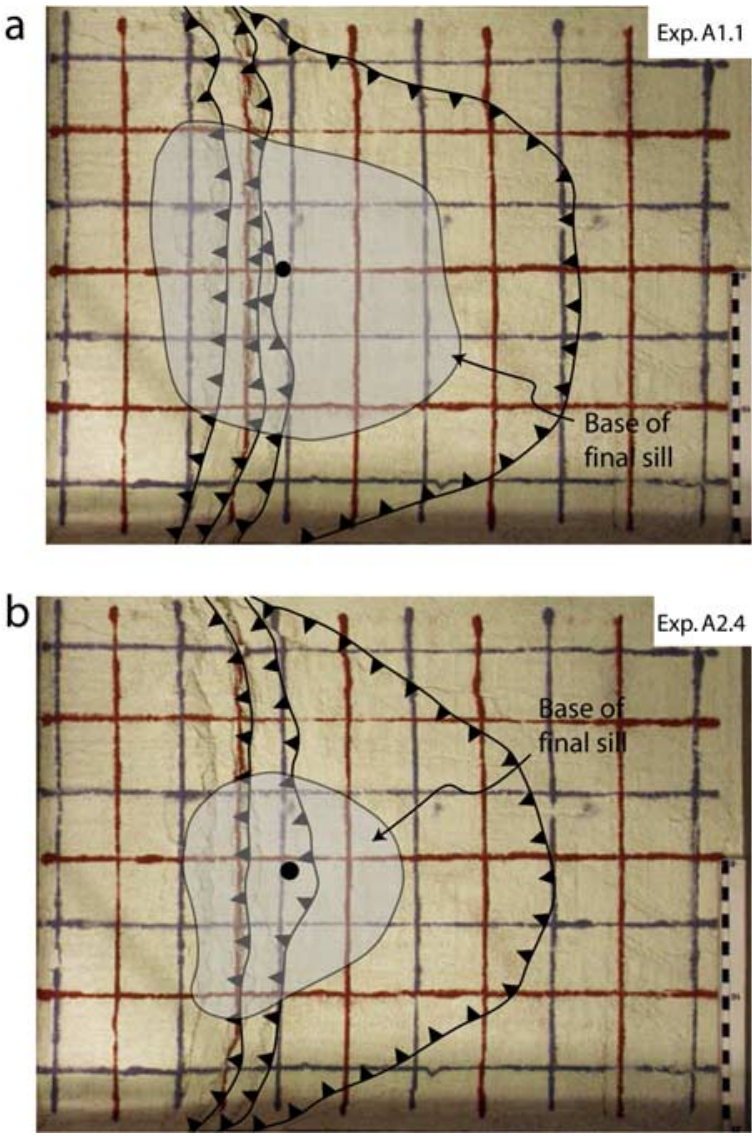

Figure 12. Coincidence of surface structures and basal sills in experiments (a) A1.1 and (b) A2.4. Surface views were taken at $t=t_{\mathrm{AT}}$, when arcuate thrust AT formed at surface. Outlines of basal sills were deduced from serial cross sections. Arcuate thrusts nucleated at peripheries of basal sills.

(Figure 13c; Table 5). Therefore whatever the values of $v_{\mathrm{p}}$ and $Q$, the arcuate thrusts always formed after about $10 \%$ shortening. Combining equations (7) and (8), a new expression for $V_{0}$ is:

$$
V_{0}=\frac{-e_{\mathrm{AT}}}{R / V_{\mathrm{m}}}+C
$$

Here $C$ is constant. As $e_{\mathrm{AT}}$ is also constant (Figure 13c), $V_{0}$ is inversely proportional to $R$ :

$$
V_{0} \propto \frac{1}{R}
$$

[48] Hence for larger values of $R$, the volume injected was smaller at the time the arcuate thrust formed. Equation (10) fits the experimental data well (Figure 13d).

[49] We have seen above (section 4.2) that the basal sill of length $L_{\mathrm{i}}$ and thickness $w$ was almost circular; a good estimate of its volume is $V \approx w \pi L_{\mathrm{i}}^{2} / 4$. Moreover, according to equation (2), the thickness of a hydraulic fracture is linearly proportional to its length. Thus at $t=t_{\mathrm{AT}}$, the volume of the sill is proportional to the cube of its length:

$$
V_{0} \propto L_{\mathrm{i}}^{3}
$$

Combining equations (10) and (11), we obtain:

$$
L_{\mathrm{i}} / h \propto R^{-1 / 3}
$$

Here $h$ is the initial thickness of a model and is constant for all experiments. According to Figure 14, the length of the plateau $L_{\mathrm{p}}$ is equal to $L_{\mathrm{i}}$, and we deduce an expression for $L_{\mathrm{p}}$ as a function of $R$ :

$$
L_{\mathrm{p}} / h \propto R^{-1 / 3}
$$

[50] Equations (12) and (13) fit the experimental results quite well; the theoretical exponents are close to those obtained experimentally $(b=-0.41 \pm 0.07$ and $b=$ $-0.36 \pm 0.05$, respectively; Figure 13).

[51] This simple physical analysis explains why the lengths of the basal sill and overlying plateau correlate inversely with the relative rates of shortening and injection, as expressed by $R$. Thus the main factor that controlled the final length of the basal sill and the plateau was the volume of oil that had been injected into the model when the arcuate thrusts formed.

\section{Comparison With Natural Examples}

[52] In many parts of the world, magmatic processes and compressional tectonics have occurred together. Here we draw attention to two examples (Figure 15), and we compare them with our experiments. In the first example, Tromen volcano in the back-arc Neuquén basin of Argentina, Quaternary volcanic rocks and structures are well exposed at the surface, so that a case can be made for contemporaneous tectonic shortening and volcanism. In the second example, the Boulder Batholith of Montana, uplift and erosion have brought to the surface deeper crustal rocks, so that a case can be made for coeval tectonic shortening and intrusion of Late Cretaceous age.

\subsection{Tromen Volcano, Neuquén Basin, Argentina}

[53] A major producer of oil and gas, the Neuquén basin has been explored in detail [Vergani et al., 1995]. It contains some $5000 \mathrm{~m}$ of sedimentary strata, of Triassic to Upper Cretaceous age. The basin formed as a rift during the early Mesozoic and further developed in a marine back-arc setting during the mid-Mesozoic. In the Late Cretaceous, it developed in a foreland setting, filling with up to $1300 \mathrm{~m}$ of alluvial and fluvial conglomerates [Cobbold and Rossello, 2003]. During the Tertiary, andesitic magma intruded and erupted in the western part of the basin [Llambias and Rapela, 1988; Jordan et al., 2001]. In the Quaternary, large volcanoes formed in the main magmatic arc but also in a back-arc position within the Andean foothills and foreland [e.g., Saal et al., 1993].

[54] Of the Quaternary back-arc volcanoes, Tromen is closest to the magmatic arc. It lies in the foothills, near the western edge of the Neuquén basin. The edifice is more than $3000 \mathrm{~m}$ high and more than $30 \mathrm{~km}$ in diameter (Figure 1b). The main period of volcanic activity was late Pliocene to Holocene [Zollner and Amos, 1973; Holmberg, 1975; Llambias et al., 1982; Galland et al., 2007]. However, Tromen is still active, it may have erupted in 1822 , 
Table 4. Results for Experiments of Series $A^{a}$

\begin{tabular}{lrrrrrrrr}
\hline Experiments & \multicolumn{1}{c}{$R$} & \multicolumn{1}{c}{$\alpha$} & $\mathrm{L}_{\mathrm{I}}, \mathrm{cm}$ & \multicolumn{1}{c}{$L_{\mathrm{p}}, \mathrm{cm}$} & \multicolumn{1}{c}{$V_{0}, \mathrm{~mL}$} & $S_{\mathrm{p}}, \mathrm{cm}^{2}$ & \multicolumn{1}{c}{$t_{\mathrm{AT}}, \mathrm{s}$} & $\mathrm{T}_{\mathrm{AT}}^{*} \times 10^{3}$ \\
\hline A1.1 & 5.7 & $5.6^{\circ}$ & 18.28 & 20.73 & $130.6 \pm 5.2$ & 602.81 & $860 \pm 60$ & $100 \pm 7$ \\
$\mathrm{~A} 1.2$ & 10.2 & $6.7^{\circ}$ & 15.98 & 13.48 & $99.2 \pm 5.2$ & 456.11 & $620 \pm 40$ & $129 \pm 8$ \\
$\mathrm{~A} 1.3$ & 15.7 & $6.8^{\circ}$ & 9.92 & 13.11 & $62.7 \pm 2.6$ & 290.40 & $410 \pm 10$ & $131 \pm 3$ \\
$\mathrm{~A} 1.3$ bis & 13.3 & $9.1^{\circ}$ & 9.24 & 9.79 & $23.50 \pm 2.6$ & 285.94 & $260 \pm 10$ & $84 \pm 3$ \\
$\mathrm{~A} 1.4$ & 22.5 & $10.7^{\circ}$ & 10.31 & 10.94 & $39.17 \pm 2.6$ & 324.86 & $250 \pm 20$ & $115 \pm 9$ \\
$\mathrm{~A} 1.5$ & 28.3 & $11.5^{\circ}$ & 10.36 & 8.98 & $33.95 \pm 2.6$ & 214.27 & $210 \pm 10$ & $121 \pm 6$ \\
$\mathrm{~A} 2.1$ & 1.9 & $3.5^{\circ}$ & 29.03 & 28.72 & $282.0 \pm 15.7$ & 714.30 & $680 \pm 40$ & $79 \pm 5$ \\
$\mathrm{~A} 2.1$ bis & 1.9 & $3.4^{\circ}$ & 28.76 & 25.18 & $313.4 \pm 31.3$ & 727.47 & $880 \pm 60$ & $102 \pm 7$ \\
$\mathrm{~A} 2.2$ & 2.3 & 4.7 & 16.02 & 19.30 & $188.0 \pm 23.5$ & 547.93 & $600 \pm 40$ & $82 \pm 5$ \\
$\mathrm{~A} 2.3$ & 3.4 & $7.0^{\circ}$ & 17.01 & 19.08 & $203.7 \pm 15.7$ & 498.13 & $500 \pm 40$ & $104 \pm 8$ \\
$\mathrm{~A} 2.4$ & 5.3 & $4.3^{\circ}$ & 15.30 & 19.02 & $109.7 \pm 7.8$ & 472.23 & $280 \pm 20$ & $90 \pm 6$ \\
$\mathrm{~A} 2.5$ & 7.5 & - & 13.41 & 16.89 & $101.8 \pm 7.8$ & 390.06 & $240 \pm 20$ & $110 \pm 9$ \\
$\mathrm{~A} 3.1$ & 15.7 & 6.8 & 9.92 & 13.11 & $62.7 \pm 2.6$ & 290.40 & $410 \pm 10$ & $131 \pm 3$ \\
$\mathrm{~A} 3.1$ bis & 13.3 & 9.1 & 9.24 & 9.79 & $23.5 \pm 2.6$ & 285.94 & $260 \pm 10$ & $84 \pm 3$ \\
A3.2 & 7.9 & 7.1 & 12.69 & 13.13 & $57.4 \pm 5.2$ & 312.26 & $270 \pm 20$ & $87 \pm 6$ \\
A3.3 & 5.3 & $4.3^{\circ}$ & 15.30 & 19.02 & $109.7 \pm 7.8$ & 472.23 & $280 \pm 20$ & $90 \pm 6$ \\
A3.4 & 4.1 & $3.9^{\circ}$ & 10.71 & 15.94 & $31.3 \pm 5.2$ & 351.67 & $190 \pm 20$ & $63 \pm 7$ \\
\hline
\end{tabular}

${ }^{\text {a }}$ For symbols, see Table A1.

according to Simkin, et al. [1981]. Its main volcanic products are widespread basaltic lava flows and a few domes of andesite or dacite [Groeber, 1929; Zollner and Amos, 1973; Holmberg, 1975; Galland et al., 2007]. According to recent ${ }^{39} \mathrm{Ar}-{ }^{40} \mathrm{Ar}$ data, Tromen has been almost continuously active since 2.5 Ma [Galland et al., 2007].

[55] The Mesozoic substratum of Tromen has shortened and thickened tectonically (Figures $1 \mathrm{~b}$ and $15 \mathrm{a}$ ). Whether the structures are thick-skinned or thin-skinned is debatable [Kozlowski et al., 1996; Zapata et al., 1999; Galland et al., 2007]. The main structure is an eastward-verging thrust system (Tromen thrust) at the eastern foot of the volcano. In its hanging wall, a series of thrust faults and anticlines have brought Jurassic evaporites to outcrop [Galland et al., 2007]. This thrust system curves around the eastern flank of Tromen and becomes straighter southward (Figure 1b).

[56] In cross section, Tromen is unusual for a volcano. The edifice consists mainly of Mesozoic strata, which have been uplifted to $3000 \mathrm{~m}$ (Figure 15a). The eruptive products are no more than a few hundred meters thick, and they lie unconformably upon the sedimentary substratum. In the hanging wall of the Tromen thrust is a large anticline, or pop-up, between thrust faults of opposite vergences.

[57] On the western flank of Tromen, although there are minor folds in the volcanic cover above westward verging thrusts (Figure 15a), most of the deformation accumulated before the onset of volcanic activity [Galland et al., 2007]. In contrast, on the eastern flank, an eastward verging arcuate thrust has involved young basalt flows. Therefore the latest phases of deformation postdated the start of volcanic activity.

[58] The main structures in Tromen are similar to those in our experiments. Thrusts and folds are arcuate around the foot of the volcano but become straighter at a distance (Figures $1 \mathrm{~b}$ and 12). The hanging wall of the arcuate thrust has been uplifted preferentially (Figures 10 and 15a). The structure is broadly asymmetric.

[59] The reasons for the arcuate shape of the Tromen thrust are debatable. Marques and Cobbold [2001, 2002, 2006] and Branquet and Van Wyk de Vries [2001] have suggested that it results from an interaction between regional shortening and loading by the volcanic edifice. However, our experiments show that coeval magmatic activity and regional shortening can produce a similar structural pattern. Because volcanic activity on Tromen was coeval with thrusting, we suspect that the structural pattern results at least in part from mechanical interactions between intrusive bodies and thrusting.

[60] In our experiments, oil erupted from arcuate thrusts at the leading edges of the plateaus, the conduits being inclined dikes (Figure 6). In contrast, on Tromen, most of the eruptions have been from the upper part of the edifice (Figure 1b). In the central part of the volcano, we observed magmatic conduits in the form of subvertical andesitic dikes, trending almost E-W [Galland et al., 2007]. On the eastern and southern flanks, E-W alignments of volcanic domes probably follow underlying fractures [Galland et al., 2007]. What accounts for these differences between the experiments and Tromen?

[61] In the experiments, vertical tension fractures formed on the surface of the plateau, in directions almost parallel to the imposed shortening (Figure 10). We attribute these structures to superposition of a local load, because of the uplifted area, on the regional stress field [Johnson, 1970]. At a shallow depth, the stress field was mainly due to the load of the uplifted area, so that the greatest stress was vertical, whereas at deeper levels the stress was mainly due to regional compression, so that the greatest stress was

Table 5. Parameters of Function Fitted to Pressure Data ${ }^{a}$

\begin{tabular}{clll}
\hline Experiment & $\Delta t, \mathrm{~s}$ & \multicolumn{1}{c}{$A$} & \multicolumn{1}{c}{$d$} \\
\hline T1 & 264 & $7,029 \pm 369$ & $-0.48 \pm 0.018$ \\
T3 & 632 & $12,085 \pm 530$ & $-0.48 \pm 0.012$ \\
A1.1 & 312 & $8,015 \pm 264$ & $-0.47 \pm 0.01$ \\
A1.2 & 107 & $17,210 \pm 1904$ & $-0.79 \pm 0.04$ \\
A1.3 & 57 & $56,851 \pm 39863$ & $-1.56 \pm 0.2$ \\
A1.4 & 31 & $4,471 \pm 2485$ & $-0.15 \pm 0.15$ \\
A2.1 & 354 & $3,956 \pm 289$ & $-0.55 \pm 0.027$ \\
A2.4 & 73 & $5,569 \pm 514$ & $-0.63 \pm 0.06$ \\
A2.5 & 51 & $3,130 \pm 21$ & $-0.34 \pm 0.02$ \\
A3.4 & 22 & $38,491 \pm 68090$ & $-1.4 \pm 0.6$ \\
\hline
\end{tabular}

${ }^{\mathrm{a}}$ Function was $P=\mathrm{A} \cdot t^{d}+\sigma_{\mathrm{n}}$. Time interval of fit was $\Delta t$. For symbols, see Table A1. 

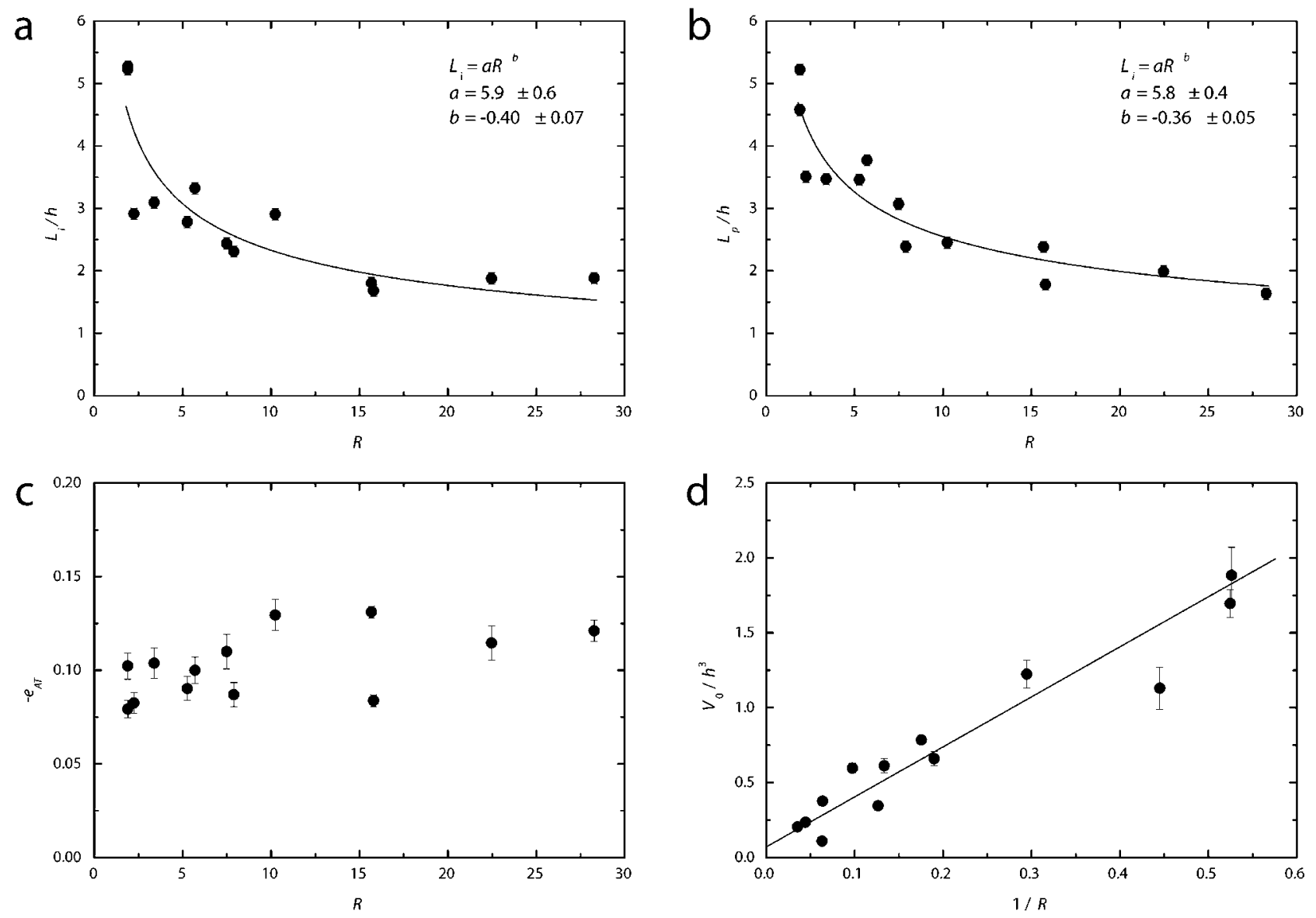

Figure 13. (a) Plot of nondimensional length of intrusion $L_{\mathrm{i}} / h$ versus kinematic ratio $R$. Note parameters (top right) for best fit hyperbola. (b) Plot of nondimensional length of plateau $L_{\mathrm{p}} / h$ versus kinematic ratio $R$. Note parameters (top right) for best fit hyperbola. (c) Plot of $e_{\mathrm{AT}}$ versus kinematic ratio $R$. To a good approximation, $e_{\mathrm{AT}}$ is constant. (d) Plot of nondimensional volume $V_{0} / h^{3}$ versus reciprocal kinematic ratio $1 / R$. Note parameters (top right) for best fit straight line. Results of experiment A3.4 have not been included.

horizontal. Although the vertical tension fractures did not serve as conduits in the experiments, similar ones might have done so on Tromen. At depth, however, we would expect magma to have formed sills or inclined sheets along thrust faults (Figures 6, 7, and 10).

[62] At Guagua Pichincha volcano, Ecuador [Legrand et al., 2002], and Miyakejima volcano, Japan [Fujita et al., 2004], where the tectonic settings are also compressional, seismic data seem to indicate subhorizontal magma transport at depth, followed by subvertical transport nearer the surface. We therefore suggest that a similar two-stage ascent has occurred under Tromen, (1) deep transport along subhorizontal sills or following a thrust fault and (2) shallow transport in subvertical dikes.

\subsection{Boulder Batholith, Montana, USA}

[63] The Boulder Batholith, an intrusive complex, crops out in Montana over an area of about $6000 \mathrm{~km}^{2}$ (Figure 15). It was emplaced into the upper crust, at a depth of less than $15 \mathrm{~km}$. It is one of the easternmost of a group of plutons in a wide batholithic belt, which may have resulted from subduction of the Eastern Pacific plate beneath continental North America.

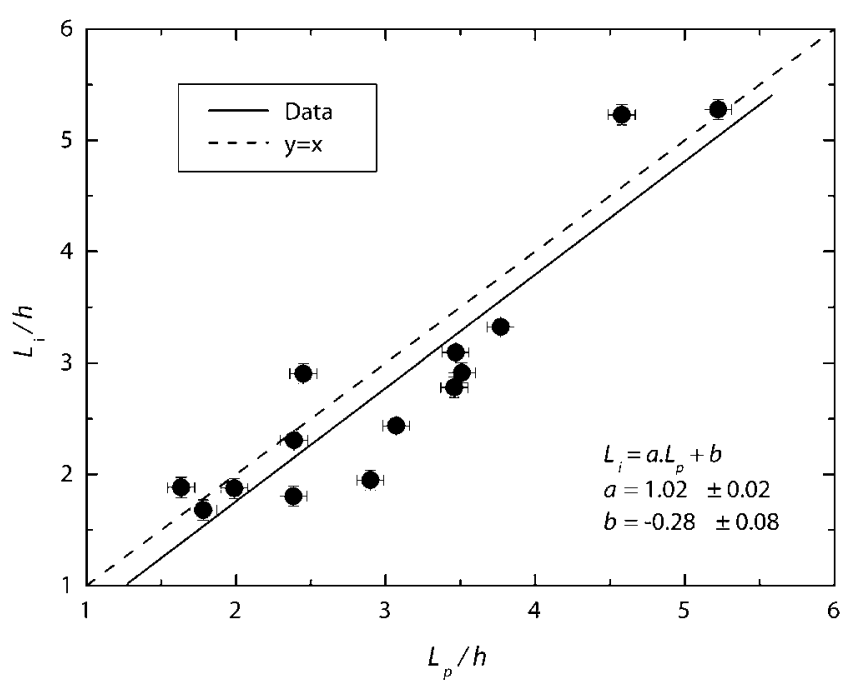

Figure 14. Plot of intrusion length $L_{\mathrm{i}}$ versus plateau length $L_{\mathrm{p}}$ for experiments of series A. Best fit straight line is close to line for $L_{\mathrm{i}}=L_{\mathrm{p}}$. Graph includes results from experiment A3.4. 


\section{Tromen volcano, Andean foothills, Neuquén basin, Argentina}

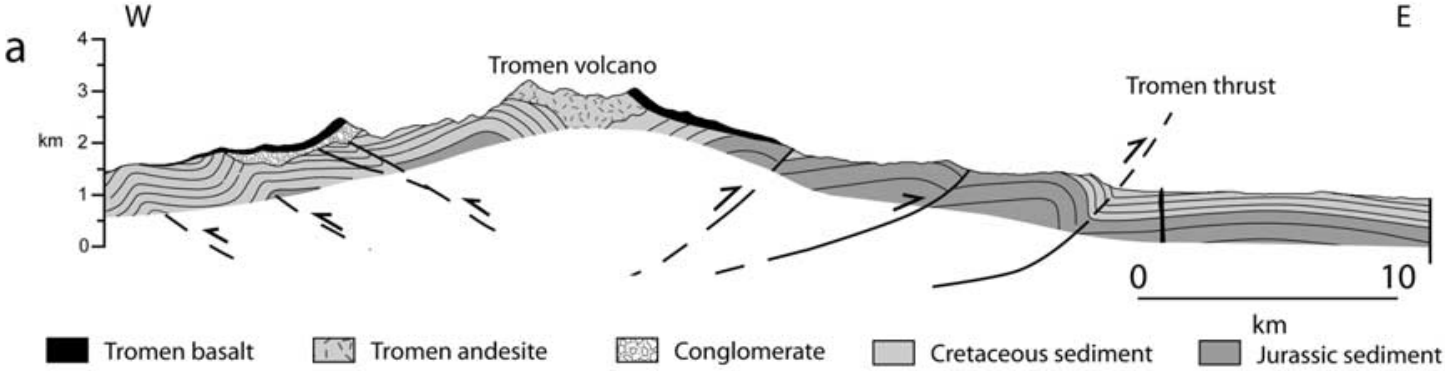

\section{Boulder Batholith, Sevier orogenic belt, Montana, USA}

b
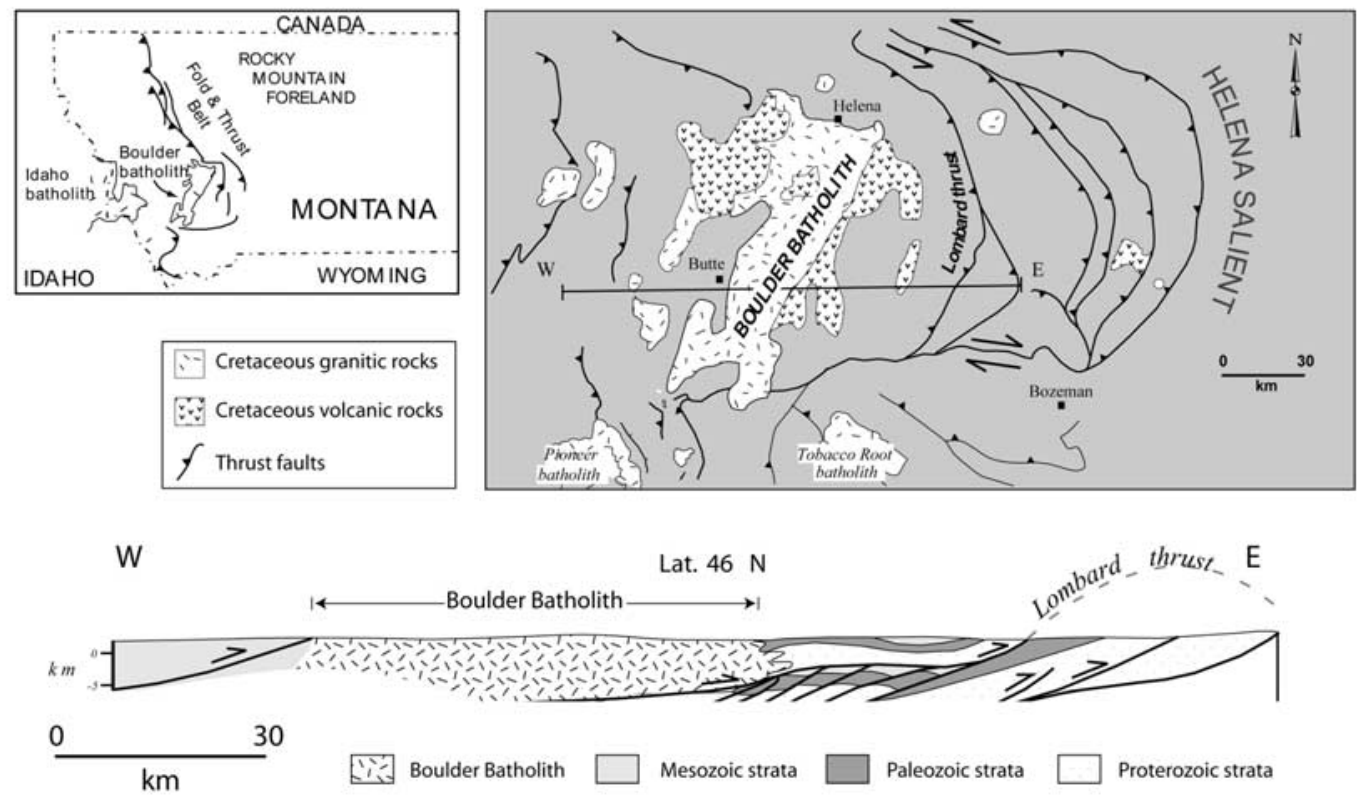

Figure 15. Two natural examples of magmatic provinces in compressional tectonic settings. (a) Cross section of Tromen volcano, Andean foothills of Neuquén basin, Argentina [after Galland et al., 2007 ]. Faults at depth are schematic. For location, see Figure 1. Main tectonic structure is east-verging Tromen thrust. Deformation was partly coeval with volcanism. (b) Geological map and cross section of Boulder Batholith in Sevier fold-and-thrust belt, Montana, USA [after Kalakay et al., 2001]. Batholith lies along Lombard thrust. Arcuate Helena Salient is at leading edge of thrust system. Deformation and intrusion were both of Late Cretaceous age.

[64] The Boulder Batholith has a tabular shape [Hamilton and Myers, 1974]. Estimates of its thickness are between 5 [Hamilton and Myers, 1974] and $12 \mathrm{~km}$ [Tilling, 1974]. The batholith was emplaced over a period of about 10 million years, during the Late Cretaceous [Tilling et al., 1968]. Thus it formed at the same time as the Sevier fold-and-thrust belt [Schmidt et al., 1990; Kalakay et al., 2001].

[65] There are strong structural and chronological relationships between the Boulder Batholith and the Sevier orogenic wedge. The batholith lies in the hanging wall of the major Lombard thrust (Figure 15b). In cross section, the Lombard thrust probably marks the lower contact of the batholith [Kalakay et al., 2001]. In the roof, the overriding rocks form an anticline. This anticline grew during the emplacement of the batholith, as a consequence of thrusting [Kalakay et al., 2001].
[66] The Helena Salient, an eastern branch of the thrust system, also formed at the same time as the batholith [Lageson et al., 2001]. The salient is arcuate in map view. Its northern and southern edges are left-lateral and rightlateral transfer zones, respectively (Figure 15b). Its arcuate shape probably resulted from interaction between tectonic shortening and intrusion. According to Lageson et al. [2001], emplacement of the Boulder Batholith inflated the Sevier orogenic wedge, so steepening its upper surface. From the theory of critical taper, such a steepening should have induced an outward transfer of deformation [Davis et al., 1983; Dahlen, 1990].

[67] However, on the basis of our experiments, we argue that there is no need for such a steepening. Instead, the unconsolidated Boulder Batholith may have lubricated the front of the Sevier wedge, so accounting for a transfer of 
deformation into the Helena Salient. The arcuate shape of the salient is what we would expect, for a fore-thrust developing at the leading edge of a tabular intrusion.

\section{Conclusions}

[68] Our experimental modeling of magmatic injection into a deforming brittle crust has focused on compressional settings. The model materials were a cohesive fine-grained silica powder (for the brittle crust) and a molten vegetable oil (for magma). The silica powder failed according to a Mohr-Coulomb criterion and the oil emplaced by hydraulic fracturing. A steadily advancing piston shortened the silica powder, while a pump injected oil at a constant rate.

[69] In the experiments, the injection rate and the piston velocity were independent variables. Shortening alone resulted in a typical thrust wedge. Injection alone resulted in a saucer-shaped intrusive body. Such bodies are common in sedimentary basins [Huuse and Mickelson, 2004; Hansen and Cartwright, 2006a].

[70] When shortening and injection were simultaneous (after an initial period of shortening alone), the oil formed a basal sill and then typically rose along a thrust fault. That the sill was basal probably reflected the contrasting mechanical properties of the silica powder and the base of the box. An arcuate thrust system nucleated at the leading edge of the sill. The hanging wall of the arcuate thrust underwent little internal deformation, but rose, to form a plateau, and slipped upon the basal sill, which acted as a weak layer.

[71] The lengths of the basal sill and overlying plateau depended on the kinematic ratio $R$ between the normalized piston velocity and the injection rate. This ratio expressed the relative rates of shortening and injection. The faster was the injection, the longer were the basal sill and plateau.

[72] Thus, in the experiments, there was a complex interplay between intrusion and compressional deformation. First, compression favored the emplacement of sills, in agreement with theoretical analysis [Hubbert and Willis, 1957]. Then, thrust faults provided conduits for oil to reach the surface. Once in place, the basal sill controlled the pattern of subsequent deformation. Being liquid and soft, it acted as a detachment, causing a thrust fault to nucleate at its leading edge. Like the outer rim of the sill, this thrust had an arcuate shape.

[73] Structures similar to those of our experiments are to be found around Tromen volcano, in the Neuquén basin of northern Patagonia, and the Boulder Batholith, in the Sevier orogenic belt of Montana, USA. In both areas, tectonic shortening and magmatic emplacement were synchronous, and arcuate thrusts formed around the main magmatic complex. On the basis of our experiments, we suggest that such features result from mechanical interactions between thrust tectonics and a partially molten magma reservoir. In such a scenario, the magma intrudes along major thrust faults. However, our experimental results cannot account for some features observed in the natural examples. For example, in our experiments, oil erupted along the traces of arcuate thrusts, whereas on Tromen volcano, eruptions occurred at the summit.

[74] In general, our experiments may provide plausible mechanisms for magma transport during thrust tectonics. We have described some first-order interactions between processes of intrusion and regional shortening. Further work is necessary to constrain such processes.

\section{Appendix A: Detailed Description of Experimental Results}

\section{A1. Basic Experiments}

\section{A1.1. Experiment $T 1(R=0)$}

[75] The oil was injected at the base of the model. At the surface of the model, a smooth circular dome and associated vertical tension fractures formed above the injection point (Figure 3). After $360 \mathrm{~s}$ of injection, oil erupted at the edge of the dome (Table 4).

[76] At depth, the oil formed an intrusive body, almost axially symmetric about the injection point (Figure 3 ). The body consisted of a basal sill, several millimeters thick, branching upward and outward into an oblique cone sheet or saucer-shaped sill. From the shape of the intrusive body, we infer that the oil was intruded by hydraulic fracturing. The dome at the surface overlay the basal sill, indicating that the overpressured oil jacked up the silica powder. Next to the intrusive body, the oil percolated over a distance of a few millimeters into the pore space of the silica powder.

\section{A1.2. Experiment $T 2(R=\infty)$}

[77] There was shortening but no injection. Deformation resulted in a series of fore-thrusts. The first one initiated against the piston. At the surface, its trace was almost straight (Figure 4a). As deformation proceeded, new forethrusts formed in sequence away from the piston, the outermost one being the most active (Figure 4a). At the end of the experiment (for a bulk shortening of $\boldsymbol{e}=-25 \%$ ), there were six thrusts, regularly spaced.

[78] In cross-section (Figure 4b), the fore-thrusts (dipping at $\sim 30^{\circ}$ ) were $5-6 \mathrm{~cm}$ apart. Steeper back thrusts (dipping at $40^{\circ}-50^{\circ}$ ) formed against the piston. The thrust wedge had an average surface slope of $\sim 17^{\circ}$.

\section{A1.3. Experiment T3}

[79] During the first phase, shortening resulted in a thrust wedge, similar to that of experiment T2 (Table 4; Figure 5a). During the second phase, $230 \mathrm{~mL}$ of oil was injected over a period of $660 \mathrm{~s}$. No oil reached the surface of the model. Instead, it formed a basal sill, branching upward into an oblique dike (Figure 5a). In contrast, with experiment T1, the intrusive body was strongly asymmetric. The oblique dike formed along a back thrust and spread horizontally more than $10 \mathrm{~cm}$ from the injection point. In all, the intrusive body was more than $25 \mathrm{~cm}$ long.

[80] The oil pressure varied as in experiment T1. From an initial peak at $\sim 7000 \mathrm{~Pa}$, the pressure decreased hyperbolically (Figure 5b).

\section{A2. Experiments of Various Durations (Series C)}

[81] Initially, the compacted silica powder was $5.5 \mathrm{~cm}$ thick (Figure 6a). After 5.3\% shortening and no injection (experiment $\mathrm{C} 1 ; t=180 \mathrm{~s}$; Table 4), two fore-thrusts had propagated out from the base of the piston (RT1 and RT2; Figure $6 \mathrm{~b}$ ). At the surface of the model, the thrust traces were straight and $\sim 3 \mathrm{~cm}$ apart.

[82] After $9.6 \%$ shortening, accompanied by injection (experiment $\mathrm{C} 2 ; t=320 \mathrm{~s}$; Table 4 ), the outer thrust was the 
Table A1. Units and Symbols

\begin{tabular}{|c|c|c|}
\hline$b$ & Fit exponent of $\mathrm{L}_{\mathrm{i}}$ and $L_{\mathrm{p}}$ versus $R$ & \\
\hline C & Cohesion & $\mathrm{Pa}$ \\
\hline$C^{*}$ & Cohesion ratio & \\
\hline$d$ & Fit exponent for $P$ versus $t$ & \\
\hline$e$ & Total shortening & \\
\hline$e_{\mathrm{AT}}$ & Shortening when AT forms & \\
\hline$e_{\mathrm{ATC}}$ & Critical value of $e_{A T}$ & \\
\hline$e_{\mathrm{i}}$ & Shortening when injection starts & \\
\hline$g$ & Acceleration due to gravity & $\mathrm{m} \mathrm{s}^{-2}$ \\
\hline$h$ & Initial thickness of model & $\mathrm{m}$ \\
\hline$L^{*}$ & Scale ratio & \\
\hline$L_{0}$ & Initial length of model & $\mathrm{m}, \mathrm{cm}$ \\
\hline$L_{\mathrm{i}}$ & Length of base of intrusive body & $\mathrm{m}, \mathrm{cm}$ \\
\hline$L_{\mathrm{p}}$ & Length of non deformed plateau & $\mathrm{m}, \mathrm{cm}$ \\
\hline$P$ & Oil pressure & $\mathrm{Pa}$ \\
\hline$P_{\mathrm{i}}$ & Pressure at injection point & $\mathrm{Pa}$ \\
\hline$Q$ & Oil injection flow rate & $\mathrm{m}^{3} \mathrm{~s}^{-1}, \mathrm{~mL} \min$ \\
\hline$R$ & Dimensionless shortening/injection rates & \\
\hline$S_{\mathrm{p}}$ & Surface of non deformed plateau & $\mathrm{m}^{2}, \mathrm{~cm}^{2}$ \\
\hline$T$ & Tensile strength & $\mathrm{Pa}$ \\
\hline$t$ & Time during experiments & $\mathrm{s}$ \\
\hline$t_{\mathrm{AT}}$ & Time of formation of AT & $\mathrm{s}$ \\
\hline$t_{\exp }$ & Duration of experiment & $\mathrm{s}$ \\
\hline$t_{\text {inj }}$ & Duration of injection & $\mathrm{s}$ \\
\hline$\Delta t$ & Fit time interval for pressure & $\mathrm{s}$ \\
\hline$V$ & Injected oil during experiment & $\mathrm{m}^{3}, \mathrm{~mL}$ \\
\hline$V_{0}$ & Injected oil when AT forms & $\mathrm{m}^{3}, \mathrm{~mL}$ \\
\hline$V_{\mathrm{i}}$ & Total oil injected & $\mathrm{m}^{3}, \mathrm{~mL}$ \\
\hline$V_{\mathrm{m}}$ & Initial volume of model & $\mathrm{m}^{3}, \mathrm{~mL}$ \\
\hline$v^{*}$ & Magma velocity ratio & \\
\hline$v_{\mathrm{p}}$ & Piston velocity & $\mathrm{m} \mathrm{s}^{-1}, \mathrm{~cm} \mathrm{~min}^{-1}$ \\
\hline$w$ & Thickness of intrusive body & $\mathrm{m}, \mathrm{cm}$ \\
\hline$\alpha$ & Surface slope of thrust wedge & \\
\hline$\beta$ & Basal slope of thrust wedge & \\
\hline$\eta^{*}$ & Magma viscosity ratio & \\
\hline$\phi$ & Angle of internal friction & \\
\hline$\mu$ & Shear modulus & \\
\hline$\rho$ & Density & $\mathrm{g} \mathrm{cm}^{3}$ \\
\hline$\rho^{*}$ & Model to nature density ratio & \\
\hline$\sigma^{*}$ & Stress ratio & \\
\hline$\sigma_{\mathrm{n}}$ & Normal stress on fracture plane & $\mathrm{Pa}$ \\
\hline$\sigma_{\mathrm{t}}$ & Tectonic stress & $\mathrm{Pa}$ \\
\hline$\sigma_{\mathrm{n}}^{*}$ & Tectonic stress ratio & \\
\hline$\sigma_{\mathrm{v}}$ & Viscous stress & $\mathrm{Pa}$ \\
\hline$\sigma_{\mathrm{v}}{ }^{*}$ & Viscous stress ratio & \\
\hline$\nu$ & Poisson's ratio & \\
\hline
\end{tabular}

more active of the two. The oil accumulated in a thin basal sill (Figure 6c). At time $t=t_{\mathrm{AT}}$ (Table A1), an arcuate fore-thrust (AT) initiated at the leading edge of the sill. The strip between fore-thrusts RT2 and AT did not deform internally, but instead slipped on the basal sill and rose, to form a plateau.

[83] After $15.6 \%$ shortening (experimenst C3; $t=520 \mathrm{~s}$; Table 4), fore-thrust AT was the most active (Figure 6d). The basal sill was thicker and somewhat longer than before.

[84] After $21.6 \%$ shortening (experiment $\mathrm{C} 4 ; t=720 \mathrm{~s}$; Table 4), two new thrusts had formed, an arcuate fore-thrust (AT') at the front of the wedge and a straight back thrust (RT3) at the rear (Figure 6e). The basal sill was thicker but no longer than that in the previous step.

\section{A3. Experiments at Various Values of $\boldsymbol{R}$ (Series A)}

[85] In Series A1 and A2, $Q$ was constant, whereas in Series A3, $\nu_{\mathrm{p}}$ was constant (Figure 7).

\section{A3.1. Series A1}

[86] In Series A1, $\nu_{\mathrm{p}}$ was between 0.4 and $2.01 \mathrm{~cm} \mathrm{~min}^{-1}$ (Table 4). The total shortening $e$ at the end of the experi- ments was about $-25 \%$, except in experiment A1.1, where it was $15.5 \%$ when the oil erupted. Experiment A1.3bis was a repetition of experiment A1.3.

[87] In every experiment, three straight fore-thrusts (RT1 to RT3) formed against the piston, whereas arcuate thrusts (AT and AT') nucleated at the leading edge of a basal sill (Figure 7). This sill was not axially symmetric. It propagated mainly in a direction away from the piston. Except in experiment A1.1, oil rose along the arcuate thrust system. In every experiment of Series A1, a plateau formed above the basal sill.

[88] For successively faster piston velocities, the plateau was shorter (Figure 8a). Despite some dispersion, most of the other measured values showed a similar tendency (Table 5).

\section{A3.2. Series A2}

[89] In Series A2, the piston velocity was between 0.4 and $1.6 \mathrm{~cm} \mathrm{~min}^{-1}$ (Table 4). The total shortening $e$ was between 10 and $25 \%$, depending on the time required for the oil to erupt. Experiment A2.1bis was a repetition of experiment A2.1.

[90] In every experiment of this series, two or three straight fore-thrusts (RT1, RT2, and RT3) formed against the piston. In experiments A2.2 to A2.5, arcuate thrusts (AT and AT') nucleated at the leading edge of a basal sill (Figure 7). In experiments A2.1 and A2.1bis, arcuate thrusts were not well formed when oil erupted at the surface, but we were able to estimate plateau lengths of $\approx 29$ and $\approx 25 \mathrm{~cm}$, respectively (Table 5). The intrusive bodies consisted mainly of basal sills, 1-3 cm thick (Figure 7). In experiment A2.2, the basal sill had a thinner splay at its leading edge (Figure 7). In experiment A2.5, the basal sill branched upward along an arcuate thrust. In every experiment of Series A2, a plateau formed above the basal sill.

[91] In general, for faster rates of shortening, the intrusive body and plateau were shorter, and arcuate thrusts formed more rapidly (Figure 8b; Table 5), as in Series A1.

\section{A3.3. Series A3}

[92] In Series A3, the injection rate was between 15.7 and $62.7 \mathrm{~mL} \mathrm{~min}^{-1}$ (Table 4). The experiments ended when oil erupted at the surface, for a total shortening between 9 and $23 \%$ (Table 4). Experiments A3.1 and A3.1bis were in fact the same ones as experiments A1.3 and A1.3bis of Series A1 (Figure 7). Also, experiment A3.3 was the same one as experiment A2.4 of Series A2. Only the labels changed.

[93] In every experiment of Series A3, straight forethrusts (RT1, RT2, and RT3) formed against the piston, whereas arcuate thrusts (AT and AT') nucleated at the leading edge of a basal sill, $\sim 2 \mathrm{~cm}$ thick (Figure 7). In experiment A3.2, oil rose along an arcuate thrust. Experiments A3.1 and A3.1bis have been described in section A3.1, and experiment A3.3 have been described in section A3.2. In experiment $\mathrm{A} 3.4$, the basal sill branched along the arcuate thrust as a thinner dike. In every experiment of Series A3, a plateau formed above the basal sill.

[94] In contrast with the previous series, faster injection rates resulted in longer plateaus (Figure 8c; Table 5). However, in all the experiments, arcuate thrusts formed after the same time interval.

[95] In experiment A3.4, the values of $L_{\mathrm{i}}, L_{\mathrm{p}}, V_{0}$, and $S_{\mathrm{p}}$ were significantly smaller than those in experiment A3.3 (Table 5), although the flow rate $\left(Q=62.7 \mathrm{~mL} \mathrm{~min}^{-1}\right)$ was 
the highest of Series A (Figure 7). We therefore suspect that the mechanism of oil emplacement was different in experiment A3.4.

\section{A3.4. Structures in Three Dimensions}

[96] For each experiment of Series A, we reconstructed the internal structures in three dimensions by interpolating between the serial cross sections (Figure 9) along the surface traces of faults. The traces of early fore-thrusts (RT1 to RT3) and of back thrusts were straight and parallel to the piston (Figure 9). However, the distance between RT3 and AT decreased, from the central cross section to the lateral ones (Figure 9). The lateral ramps of AT were steeper than one might infer from the serial sections alone.

[97] The basal sill was more than $15 \mathrm{~cm}$ long. In those experiments where oil did not reach the surface (for example, experiment A1.2; Figure 9b), the intrusive body consisted of a basal sill, in some examples branching into a dike along the frontal arcuate thrust, AT. In contrast, in those experiments where oil reached the surface (for example, experiment A1.1; Figure 9a), it did so along the lateral ramps of the arcuate thrust. The intrusive body therefore consisted of a basal sill, branching into a dike (or dikes) along the lateral ramps.

[98] Acknowledgments. Funds for this work came from TOTAL Austral S.A. and CNRS. The experiments were done in the physical modeling laboratory of Géosciences-Rennes. The authors thank $M$ Lemoine and J.-P. Caudal for building the experimental apparatus and for technical help. O. Galland acknowledges a PhD salary from the Ministère de l'Enseignement Supérieur et de la Recherche, France. D. Gapais, O. Merle, S. Planke, R.S.J. Sparks, J.-P. Thiriet, and Y. Podladchikov provided useful discussion. Constructive reviews from P. D. Bons and an anonymous reviewer, and comments from Associate Editor W. P. Schellart, all helped to improve the manuscript.

\section{References}

Ancochea, E., J. L. Brändle, M. J. Huertas, C. R. Cubas, and F. Hernan (2003), The felsic dikes of La Gomera (Canary Islands): Identification of cone sheet and radial dike swarms, J. Volcanol. Geotherm. Res., 120, $197-206$

Ballard, J.-F., J.-P. Brun, J. Van den Driessche, and P. Allemand (1987), Propagation des chevauchements au-dessus des zones de décollement: Modèles expérimentaux, C. R. Acad. Sci., Ser. IIA: Terre Planetes, t305, 1249-1253.

Barberi, G., O. Cocina, G. Nery, E. Privitera, and S. Spampinato (2000), Volcanological inferences from seismic-strain tensor computations at Mt. Etna Volcano, Sicily, Bull. Volcanol., 62, 318-330.

Branquet, Y., and B. Van Wyk de Vries (2001), Effets de la charge des édifices volcaniques sur la propagation de structures régionales compressives: Exemples naturels et modèles expérimentaux, C. R. Acad. Sci., Ser. IIA: Terre Planetes, 333, 455-461.

Clavero, J. E., R. S. J. Sparks, M. S. Pringle, E. Polanco, and M. C. Gardeweg (2004), Evolution and volcanic hazards of Taapaca Volcanic Complex, Central Andes of Northern Chile, J. Geol. Soc. (London), 161, $603-618$.

Clemens, J. D., and C. K. Mawer (1992), Granitic magma transport by fracture propagation, Tectonophysics, 204, 339-360.

Cobbold, P. R., and E. A. Rossello (2003), Aptian to recent compressional deformation, foothills of Neuquén Basin, Argentina, Mar. Pet. Geol., 20, 429-443.

Corry, C. E. (1988), Laccoliths; mechanisms of emplacement and growth, Geol. Soc. Am., Spec. Pap. 220, 110 pp.

Corti, G., M. Bonini, S. Conticelli, F. Innocenti, P. Manetti, and D. Sokoutis (2003), Analogue modelling of continental extension: A review focused on the relations between the patterns of deformation and the presence of magma, Earth-Sci. Rev., 63, 169-247.

Couzens-Schultz, B. A., B. C. Vendeville, and D. V. Wiltschko (2003), Duplex style and triangle zone formation: Insights from physical modeling, J. Struct. Geol., 25, 1623-1644.

Dahlen, F. A. (1990), Critical taper model of fold-and-thrust belts and accretionary wedges, Annu. Rev. Earth Planet. Sci., 18, 55-90.
Davis, D., J. Suppe, and F. A. Dahlen (1983), Mechanics of thrust-and-fold belts and accretionary prisms, J. Geophys. Res., 88, 1153-1172.

Fialko, Y. (2001), On origin of near-axis volcanism and faulting at fast spreading mid-ocean ridges, Earth Planet. Sci. Lett., 190, 31-39.

Fialko, Y., and M. Simons (2001), Evidence for on-going inflation of the Socorro magma body, New Mexico, from interferometric synthetic aperture radar imaging, Geophys. Res. Lett., 28, 3549-3552.

Fujita, E., M. Ukawa, and E. Yamamoto (2004), Subsurface cyclic magma sill expansions in the 2000 Miyakejima volcano eruption: Possibility of two-phase flow oscillation, J. Geophys. Res., 109, B04205, doi:10.1029/ 2003JB002556.

Galland, O. (2005), Interactions mécaniques entre la tectonique compressive et le magmatisme: Expériences analogiques et exemple naturel, Mémoires de Géosciences-Rennes, no. 116, 411 pp., Rennes, url: http://tel. archives-ouvertes.fr/documents/archives0/00/00/84/98/index fr.html.

Galland, O., J. de Bremond d'Ars, P. R. Cobbold, and E. Hallot (2003), Physical models of magmatic intrusion during thrusting, Terra Nova, 15, 405-409.

Galland, O., P. R. Cobbold, E. Hallot, J. de Bremond d'Ars, and G. Delavaud (2006), Use of vegetable oil and silica powder for scale modelling of magmatic intrusion in a deforming brittle crust, Earth Planet. Sci. Lett., 243, 786-804.

Galland, O., E. Hallot, P. R. Cobbold, G. Ruffet, and J. de Bremod d' Ars (2007), Volcanism in a compressional Andean setting: A structural and geochronological study of Tromen volcano (Neuquén province, Argentina), Tectonics, doi:10.1029/2006TC002011, in press.

Gilbert, G. K. (1877), Report on the geology of the Henry Mountains, 160 pp., US Geogr. Geol. Surv. Rocky Mountain Region (Powel).

Glazner, A. F. (1991), Plutonism, oblique subduction, and continental growth: An example from the Mesozoic of California, Geology, 19 $784-786$.

González, P. D., and E. Aragón (2000), El Cerro Bayo de la Sierra Negra, Neuquén: Ejemplo de un lacolito tipo Arbol de Navidad, Rev. Asoc. Geol. Argent., 55, 363-377.

Gray, J. P., and J. J. Monaghan (2004), Numerical modelling of stress fields and fracture around magma chambers, J. Volcanol. Geotherm. Res., 135, $259-283$.

Griffith, A. A. (1921), The phenomena of rupture and flow in solids, Philos. Trans. R. Soc. London, Ser. A, 221, 163-198.

Griffith, A. A. (1924), The theory of rupture, in Proc. First Int. Congr Appl. Mech., edited by C. B. Biezeno and J. M. Burgers, pp. 55-63, J. Waltman, Delft.

Groeber, P. (1929), Líneas fundamentales de la geología del Neuquén, sur de Mendoza y regiones adyacentes, 110 pp., Ministerio de Agricultura, Dirección General de Minas, Geología y Hidrología, Buenos Aires.

Gudmundsson, A. (1984), Tectonic aspects of dykes in northwestern Iceland, Jokull, 34, 81-96.

Gudmundsson, A. (1998), Magma chambers modeled as cavities explain the formation of rift zone central volcanoes and their eruption and intrusion statistics, J. Geophys. Res., 103, 7401-7412.

Gudmundsson, A. (2002), Emplacement and arrest of sheets and dykes in central volcanoes, J. Volcanol. Geotherm. Res., 116, 279-298.

Haederle, M., and M. P. Atherton (2002), Shape and intrusion style of the Coastal Batholith, Peru, Tectonophysics, 345, 17-28.

Hamilton, W., and W. B. Myers (1974), Nature of the Boulder Batholith of Montana, Geol. Soc. Am. Bull., 85, 365-378.

Hamilton, W. B. (1995), Subduction systems and magmatism, in Volcanism Associated With Extension at Consuming Plate Margins, edited by J. L. Smellie, Geol. Soc. London, Spec. Publ. 81, pp. 3-28.

Hansen, D. M., and J. A. Cartwright (2006a), Saucer-shaped sill with lobate morphology revealed by 3D seismic data: Implications for resolving a shallow-level sill emplacement mechanism, J. Geol. Soc. (London), 163, $509-523$.

Hansen, D. M., and J. A. Cartwright (2006b), The three-dimensional geometry and growth of forced folds above saucer-shaped igneous sills, J. Struct. Geol, 28, 1520-1535.

Haschke, M., and A. Günther (2003), Balancing crustal thickening in arcs by tectonics vs. magmatic means, Geology, 31, 933-936.

Helgason, J., and M. Zentilli (1985), Field characteristics of laterally emplaced dikes: Anatomy of an exhumed Miocene dike swarm in Reydarfjordur, eastern Iceland, Tectonophysics, 115, 247-274.

Holmberg, E. (1975), Descripción geológica de la Hoja 32c, Buta Ranquil (Prov. Mendoza-Neuquén), Bull. 152, 71 pp., Serv. Nac. Min. Geol., Buenos Aires.

Hubbert, M. K., and D. G. Willis (1957), Mechanics of hydraulic fracturing, in Structural Geology, edited by M. K. Hubbert, pp. 175-190, Macmillan, New York.

Huiqi, L., K. R. McClay, and D. Powell (1992), Physical models of thrust wedges, in Thrust Tectonics, edited by K. R. McClay, pp. 71-81, CRC Press, Boca Raton, Fla. 
Hutton, D. H. W. (1997), Syntectonic granites and the principles of effective stress: A general solution to the space problem?, in Granite: From Segregation of Melt to Emplacement Fabrics, edited by J. L. Bouchez, D. H. W. Hutton, and W. E. Stephens, pp. 189-197, Springer, New York.

Huuse, M., and M. Mickelson (2004), Eocene sandstone intrusions in the Tampen Spur area (Norwegian North Sea Quad 34) imaged by 3D seismic data, Mar Pet. Geol., 21, 141-155.

Ida, Y. (1999), Effects of the crustal stress on the growth of dikes: Conditions of intrusion and extrusion of magma, J. Geophys. Res., 104, 17,897-17,909.

Inglis, C. E. (1913), Stresses in a plate due to the presence of cracks and sharp corners, Trans. R. Inst. Nav. Archit., 55, 219-230.

Irwin, G. R. (1958), Fracture, in Encyclopedia of Physics, edited by S. Flugge, pp. 551-590, Springer, New York.

Johnson, A. M. (1970), Physical processes in geology, 592 pp., W. H. Freeman, New York.

Jordan, T. E., W. M. Burns, R. Veiga, F. Pángaro, P. Copeland, S. Kelley, and C. Mpodozis (2001), Extension and basin formation in the southern Andes caused by increased convergence rate: A mid-Cenozoic trigger for the Andes, Tectonics, 20, 308-324.

Kalakay, T. J., B. E. John, and D. R. Lageson (2001), Fault-controlled pluton emplacement in the Sevier fold-and-thrust belt of southern Montana, J. Struct. Geol., 23, 1151-1165.

Kendrick, E. C., M. Bevis, R. F. J. Smalley, and B. Brooks (2001), An intergated crustal velocity field for the Central Andes, Geochem. Geophys. Geosyst., 2, doi:10.1029/2001GC000191.

Kozlowski, E. E., C. E. Cruz, and C. A. Sylwan (1996), Geología estructural de la zona de Chos Malal, Cuenca Neuquina, Argentina, paper presented at XIII Congreso Geológico Argentino y III Congreso de Exploración de Hidrocarburos, p. 15-26.

Krantz, R. W. (1991), Measurements of friction coefficients and cohesion for faulting and fault reactivation in laboratory models using sand and sand mixtures, Tectonophysics, 188, 203-207.

Lageson, D. R., J. G. Schmitt, B. K. Horton, T. J. Kalakay, and B. R. Burton (2001), Influence of Late Cretaceous magmatism on the Sevier orogenic wedge, western Montana, Geology, 29, 723-726.

Legrand, D., A. Calahorrano, B. Guillier, L. Rivera, M. Ruiz, D. Villagomez, and H. Yepes (2002), Stress tensor analysis of the 1998-1999 tectonic swarm of northern Quito related to the volcanic swarm of Guagua Pichincha volcano, Ecuador, Tectonophysics, 344, 15-36.

Lister, J. R., and R. C. Kerr (1991), Fluid-mechanical models of crack propagation and their application to magma transport in dykes, J. Geophys. Res., 96, 10049-10077.

Llambías, E. J., and C. W. Rapela (1988), Las volcanitas de Collipilli, Neuquén $\left(37^{\circ} \mathrm{S}\right)$ y su relación con otras unidades paleógenas de la cordillera, Rev. Asoc. Geol. Argent., 44, 224-236.

Llambías, E. J., M. Palacios, and J. C. Danderfer (1982), Las erupciones holocenas del volcán Tromen (Provincia del Neuquén) y su significado en un perfil transversal E-O a la latitud de $37^{\circ} \mathrm{S}$, paper presented at Quinto Congreso Latinoamericano de Geologia, Buenos Aires, 537-545.

Malavieille, J. (1984), Modélisation expérimentale des chevauchements imbriqués: Application aux cha1circ;nes de montagnes, Bull. Soc. Géol. Fr. XXVI, 129-138.

Malthe-Sørenssen, A., S. Planke, H. Svensen, and B. Jamtveit (2004) Formation of saucer-shaped sills, in Physical Geology of High-Level Magmatic Systems, edited by C. Breitkreuz and N. Petford, Geol. Soc. London Spec. Publ., 234, pp. 215-227.

Mandl, G., L. N. J. de Jong, and A. Maltha (1977), Shear zones in granular material: An experimental study of their structure and mechanical genesis, Rock Mech., 9, 95-144.

Marques, F. O., and P. R. Cobbold (2001), Topographic controls on deformation partitioning, decoupling and vertical-axis rotations in thrust belts: Insights from sandbox modelling, paper presented at Eur. U. Geosc. 11 Meeting, Strasbourg, Abstracts.

Marques, F. O., and P. R. Cobbold (2002), Topography as a major factor in the development of arcuate thrust belts: Insights from sandbox experiments, Tectonophysics, 348, 247-268.

Marques, F. O., and P. R. Cobbold (2006), Effects of topography on the curvature of fold-and-thrust belts during shortening of a 2-layer model of continental lithosphere, Tectonophysics, 415, 65-80

Merle, O., and B. Vendeville (1995), Experimental modelling of thinskinned shortening around magmatic intrusions, Bull. Volcanol., 57, $33-43$.

Minakami, T., T. Ishikawa, and K. Yagi (1951), The 1944 eruption of volcano Usu in Hokkaido, Japan, Bull. Volcanol., 11, 5-157.

Moreau, C., D. Ohnenstetter, H. Diot, D. Demaiffe, and W. L. Brown (1995), Emplacement of the Meugueur-Meugueur cone-sheet (Niger, West Africa), one of the world's largest igneous ring-structures, in Physics and Chemistry of Dykes, edited by G. Baer and A. Heimann, pp. 41-49, A.A. Balkema, Brookfield, Vt.
Moyen, J.-F., A. Nédélec, H. Martin, and M. Jayananda (2001), Contrasted granite emplacement modes within an oblique crustal section: The Closepet granite, South India, Phys. Chem. Earth, 26, 295301.

Murdoch, L. C. (1993), Hydraulic fracturing of soil during laboratory experiments: Part 3. Theoretical analysis, Géotechnique, 43, 277-287.

Murdoch, L. C (2002), Mechanical analysis of idealized shallow hydraulic fracture, J. Geotech. Geoenviron. Eng., 128, doi:10.1061/(ASCE)10900241(2002)128:6(488).

Musumeci, G., F. Mazzarini, G. Corti, M. Barsella, and D. Montanari (2005), Magma emplacement in a thrust ramp anticline: The Gavorrano Granite (northern Apennine, Italy), Tectonics, 24, TC6009, doi:10.1029/ 2005 TC001801.

Norabuena, E., L. Leffler-Griffin, A. Mao, T. Dixon, S. Stein, S. Sacks, L. Ocola, and M. Ellis (1998), Space geodetic observations of NazcaSouth America convergence across the Central Andes, Science, 279, $358-362$

Petford, N. (1996), Dykes or diapirs?, Trans. R. Soc. Edinburgh: Earth Sci., $87,105-114$

Phillips, W. J. (1974), The dynamic emplacement of cone sheets, Tectonophysics, 24, 69-84.

Pollard, D. D. (1987), Elementary fracture mechanics applied to the structural interpretation of dikes, in Mafic Dyke Swarms, edited by H. C. Halls and W. F. Fahrig, Geol. Assoc. Can. Spec. Pap., 34, pp. 5-24.

Pollard, D. D., and G. Holzhausen (1979), On the mechanical interaction between a fluid-filled fracture and the Earth's surface, Tectonophysics, $53,27-57$.

Rivalta, E., and T. Dahm (2006), Acceleration of buoyancy-driven fractures and magmatic dikes beneath the free surface, Geophys. J. Int., 166, 1424-1439, doi:10.1111/j.1365-246X.2006.02962.x.

Roman, D. C., J. A. Power, S. C. Moran, K. V. Cashman, M. P. Doukas, C. A. Neal, and T. M. Gerlach (2004), Evidence for dike emplacement beneath Iliamna Volcano, Alaska in 1996, J. Volcanol. Geotherm. Res., 130, 265-284.

Rubin, A. M. (1993), Dikes vs. diapirs in viscoelastic rock, Earth Planet. Sci. Lett., 119, 641-659.

Rubin, A. M. (1995a), Propagation of magma-filled cracks, Annu. Rev. Earth Planet. Sci., 23, 287-336.

Rubin, A. M. (1995b), Getting granite dikes out of the source region, J. Geophys. Res., 100, 5911-5929.

Rubin, A. M., and D. D. Pollard (1987), Origins of blade-like dikes in volcanic rift zones, in Volcanism in Hawaii, vol 2, edited by R. W. Decker, T. L. Wright, and P. H. Stauffer, pp. 1449-1470, US Geological Survey Professional Paper, 1350.

Saal, A., F. A. Frey, D. Delphino, and A. Bermudez (1993), Geochemical characteristics of alkalic basalts erupted behind Andean Volcanic Front $\left(35^{\circ}-37^{\circ} \mathrm{S}\right)$ : Constraints on sources and processes involved in continental arc magmatism. Abstract, paper presented at EOS Trans. AGU, 74(43), Fall Meet. Suppl., F652.

Schaer, J.-P. (1995), Eugène Wegmann (1896-1982) vie et oeuvre d'un géologue européen, Mém. Soc. Géol. Fr., 168, 13-23.

Schäfer, K. H., and M. Dannapfel (1994), State of in situ Stress in Northern Chile and in Northwestern Argentina, in Tectonics of the Southern Central Andes. Structure and evolution of an active continental margin, edited by K.-J. Reuter, E. Scheuber, and P. J. Wigger, pp. 103-110, Springer, New York.

Schellart, W. P. (2000), Shear test results for cohesion and friction coefficients for different materials: Scaling implications for their usage in analogue modelling, Tectonophysics, 324, 1-16.

Schmidt, C. J., H. W. Smedes, and J. M. O’Neil (1990), Syncompressional emplacement of the Boulder and Tobacco root batholiths (Montana-USA) by pull-apart along old fault zones, Geol. J., 25, 305-318.

Sibson, R. H. (2003), Brittle-failure controls on maximum sustainable overpressure in different tectonic regimes, Am. Assoc. Pet. Geol. Bull., 87, 901-908.

Sigurdsson, H. (1987), Dyke injection in Iceland: A review, in Mafic dyke swarms, edited by H. C. Halls and W. F. Fahrig, Geol. Assoc. Can. Spec. Pap., 34, pp. 55-64.

Simancas, J. F., et al. (2004), The seismic crustal structure of the OssaMorena Zone and its geological interpretation, J. Iberian Geol., 30, $133-$ 142.

Simkin, T., L. Siebert, L. McClelland, D. Bridge, C. Newhall, and J. H. Latter (1981), Volcanoes of the World, Van Nostrand Reinhold, Hoboken, N. J.

Smit, J. H. W. J.-P. Brun, and D. Sokoutis (2003), Deformation of brittleductile thrust wedges in experiments and nature, J. Geophys. Res., 108(B10), 2480, doi:10.1029/2002JB002190.

Storti, F., F. Salvani, and K. McClay (1997), Fault-related folding in sandbox analogue models of thrust wedges, J. Struct. Geol., 19, 583-602.

Tibaldi, A. (2005), Volcanism in compressional tectonic settings: Is it possible?, Geophys. Res. Lett., 32, L06309, doi:10.1029/2004GL021798. 
Tilling, R. I. (1974), Estimating the "thickness" of the Boulder Batholith, Montana, from heat flow and heat-productivity data, Geology, 2, 457-460.

Tilling, R. I., M. R. Klepper, and J. D. Obradovich (1968), K-Ar ages and time span of emplacement of the Boulder Batholith, Montana, Am. J. Sci., 266, 671-689.

Tornos, F., and C. Casquet (2005), A new scenario for related IOGC and $\mathrm{Ni}-(\mathrm{Cu})$ mineralization: The relationship with giant mid-crustal mafic sills, Variscan Iberian Massif, Terra Nova, 17, 236-241.

van Wyk de Vries, B., S. Self, P. W. Francis, and L. Keszthelyi (2001), A gravitational spreading origin for the Socompa debris avalanche, J. Volcanol. Geotherm. Res., 105, 225-247.

Vergani, G. D., A. J. Tankard, H. J. Belotti, and H. J. Welsink (1995), Tectonic evolution and paleogeography of the Neuquén basin, Argentina, in Petroleum Basins of South America, edited by A. J. Tankard, R. Suárez, and H. J. Welsink, Amer. Assoc. Petrol. Geol. Mem., 62, 383-402.

Vigneresse, J.-L., B. Tikoff, and L. Améglio (1999), Modification of the regional stress field by magma intrusion and formation of tabular granitic plutons, Tectonophysics, 302, 203-224.
Watanabe, T., T. Koyaguchi, and T. Seno (1999), Tectonic stress controls on ascent and emplacement of magmas, J. Volcanol. Geotherm. Res., 91, $65-78$.

Zapata, T. R., I. Brissón, and F. Dzelalija (1999), La estructura de la faja plegada y corrida andina en relación con el control del basamento de la Cuenca Neuquina, pp. 112-121, Boletín de Informaciones Petroleras, December 1999.

Zollner, W., and A. J. Amos (1973), Descripción geológica de la Hoja 32b, Chos Malal (Prov. Neuquén), Bull. 143, 91 pp., Serv. Nac. Min. Geol., Buenos Aires.

J. de Bremond d'Ars, P. R. Cobbold, and E. Hallot, Géosciences Rennes UMR 6118 CNRS, Université de Rennes1, Campus de Beaulieu, F-35042 Rennes Cedex, France. (bremond@univ-rennes1.fr; peter.cobbold@ univ-rennes1.fr; erwan.hallot@univ-rennes1.fr)

O. Galland, Physics of Geological Processes (PGP), Postbox 1048 Blindern, N-0316 Oslo, Norway. (olivier.galland@fys.uio.no) 